\author{
Pr. lect. univ. dr. Lucian Petroaia, \\ Facultatea de Istorie, Filosofie și Teologie, \\ Universitatea „Dunărea de Jos“ din Galați
}

\title{
PROGRAME \\ PASTORAL-MISIONARE ȘI FILANTROPICE ALE ARHIEPISCOPIEI DUNĂRII DE JOS, ÎN TIMPUL PANDEMIEI DE COVID-19
}

\begin{abstract}
Covid-19: a conventional medical code that, until the end of 2019, said nothing tous, the Europeans. The disease, which appeared in Asia, didn't seem to affect the "old continent", but unexpectedly fast and virulent, reached in all parts of the world; in Europe and in our country, too. Gradual forbid dances followed, and until the setting of the "emergency state", with its rough restrictions in the confinement months imposed by the sanitary norms, it wasn't too long. The spectrum of the disease with unknown, unpredictable manifestations, as well as the subliminal tension, with psychotic effect, "fed" by the alarmist news of the media, emphasized the human person's fear and amplified the social crisis.

However, life in Christ continued pulsing, both in the holy places, inaccessible to believers for a time and in all the houses where Christians live. But, in it's theandric being, the Church was not affected by this crisis! Moreover, the Church has turned the whole situation in the country into a dynamic motivation for its sanctifying mission in the world, for its pro-human work and for maintaining the optimistic perspective that every Christian is called to adopt, especially in painful times. For the all Romanian Orthodox Christians, Lent, Easter, Holy Week and the Easter time (March, April and May of the year of salvation 2020) were times of "enlightenment as through fire" (I Corinthians 1:13) of hope and exercise of "the working faith by love" (Galatians 5:6).

It followed a long period (July - October 2020) of "alert status" period, people being tense at the risk of a "second wave of the epidemic", a foreshadowed aspect by the growing number of diseases (in September between 1.300 and 1.700 people with positive tests per day). It is essential the way we know how to capitalize on the joy and fruits of solitary prayer during the "emergency state", continued by the "prayer of community prayer" which lit up even more during the "alert status" period. We mustn't lose the fruits of personal will / need irrigated by the living of the ecclesial life, centered
\end{abstract}


on the Savior Christ, "the Doctor of our souls and bodies" and "the Source of our life", temporary and - especially - of the eternal one, with Him!

This short article tries to show / present, synthesized, the way in which the Holy Archdiocese of the Lower Danube knew how to managed he situation created by the pandemic, through a dense liturgical and spiritual program and through balanced pastoral-missionary-social strategies, to overcome one of the most complicated periods in the recent history, which has brought emotional or physical suffering to many Christians.

Keywords: Lower Danube Archdiocese, pandemic, crisis, pastoral care, education, philanthropy, missionary strategy.

\section{Preliminarii}

Covid-19: un cod medical convențional care, până la finalul anului 2019, nouă, europenilor nu ne spunea mai nimic. Boala, apărută în spațiul asiatic, părea că nu va afecta "bătrânul continent", dar, neașteptat de repede și de virulent, a ajuns în toate laturile lumii; și în Europa, și în țara noastră. Au urmat opreliști treptate, iar până la instalarea „stării de urgență“, cu asprele ei restricții din lunile de claustrare impusă de normele sanitare nu a fost prea mult timp. Spectrul bolii cu manifestări necunoscute, imprevizibile, cât și tensiunea subliminală, cu efect psihotic, „hrănită“ de știrismul alarmist al mass-media au accentuat frica persoanei umane și au amplificat criza socială.

$\mathrm{Cu}$ toate acestea, viața în Hristos a pulsat în continuare, atât în sfintele locașuri, inaccesibile o vreme credincioșilor, cât și în toate casele unde trăiesc creștini. Însă, în ființa sa, teandrică, Biserica nu a fost afectată de această criză! Mai mult chiar, Biserica Ortodoxă Română a convertit întreaga situație din țară într-o motivație dinamizantă pentru menirea ei sfinţitoare în lume, pentru lucrarea ei pro-om și pentru menținerea perspectivei optimiste pe care fiecare creștin este chemat să o adopte, mai cu seamă în perioade de încercare. Pentru suflarea creștină ortodoxă din România, Postul Mare, Paștile, Săptămâna Luminată și perioada pascală (lunile martie, aprilie și mai din anul mântuirii 2020) au fost timpi de "lămurire ca prin foc" (I Corinteni 1,13) a speranței și de exercitare a "credinței lucrătoare prín iubire" (Galateni $5,6)$.

A urmat o lungă perioadă (iulie - octombrie 2020) de „stare de alertă“, oamenii fiind crispați de riscul venirii unui „al doilea val al epi- 
demiei“, aspect prefigurat de numărul, zilnic în creștere, al îmbolnăvirilor: în septembrie între 1.300 și 1.700 , la jumătatea lui octombrie spre 3.000 de „pozitivi“ pe zi. Este esenţial modul în care vom ști să valorificăm bucuria și roadele rugăciunii solitare din timpul „stării de urgență“, continuată de „rugul rugăciunii“" comunitare care s-a aprins și mai mult în perioada "de alertă“. Nu trebuie să pierdem roadele nevoinței personale irigate de viul vieții eclesiale, centrate pe Mântuitorul Hristos, „Doctorul sufletelor și al trupurilor noastre“ și „Izvorul vieții noastre", temporare și - mai cu seamă - al celei veșnice, cu El!

Scurtul material de față încearcă să prezinte, sintetizat, modul în care Sfânta Arhiepiscopie a Dunării de Jos a știut să gestioneze situația creată de pandemie, printr-un dens program liturgic și duhovnicesc și prin strategii pastoral-misionar-sociale echilibrate, pentru a depăși una dintre cele mai complicate perioade din istoria recentă, care a adus suferință sufletească sau trupească, multora dintre creștini.

\section{Racordarea lucrării pastoral-misionare din Arhiepiscopia Dunării de Jos la strategia Bisericii Ortodoxe Române în perioada pandemiei}

Deodată cu finalul lunii februarie 2020, pandemia a lovit din plin și țara noastră, efectele ei colaterale afectând toate mecanismele (de la economie la învățământ), toate persoanele (de la înalți oficiali, la oameni simpli) și toate dimensiunile vieții (de la simpla relaționare socială, la viața duhovnicească). Restricțiile s-au asprit pe măsură ce criza creată de pandemie s-a agravat. Ca instituție reprezentativă și cu un rol duhovnicesc - „matern“ esențial pentru viața poporului ei dreptcredincios, Biserica Ortodoxă Română s-a angajat într-o luptă titanică de susținere spirituală și de ajutorare materială a tuturor fiilor ei, îndeosebi a celor îmbolnăviți, a familiilor acestora și a celor afectați indirect, dar grav. Obiectivul major al acestei lupte a fost protejarea vieții și a sănătății oamenilor, care trebuie percepute, îngrijite și sporite ca „daruri ale lui Dumnezeu“1. Principiile de operare în această

1. Preafericitul Părinte DANIEL, Patriarhul Bisericii Ortodoxe Române, „Rugăciunea pentru încetarea pandemiei", vezi http://www.mediafax.ro.social (accesat la 
confruntare asumată de Biserica noastră au fost formulate încă de la început și anunțate preoțimii, cinului monahal și poporului prin Biroul de presă al Patriarhiei Române, care solicita ca

„toți preoții (...) să pună în aplicare, cu realism, luciditate și încredere, măsurile impuse de autorități (...), în această perioadă fiind esențiale rugăciunea și responsabilitatea pentru sănătatea personală și socială, precum și ajutorarea concretă a celor din nevoi ${ }^{2}$.

Înțelepciunea Preafericitului Patriarh al României, care a înțeles lucid și adânc pericolul grav ce se anunța, a generat un bun dialog cu autoritățile centrale. Astfel, s-au identificat cele mai bune soluții pentru ca Biserica să își păstreze relevanța sa și rolul său esențial, de suport spiritual, moral și social al fiilor ei. Astfel, restricțiile impuse de Ordonanțele Militare nr. 1/17 martie, nr. 2/21 martie, nr. 3/24 martie și de cele care au mai urmat nu au dus la închiderea totală a sfintelor locașuri, așa cum s-a petrecut în alte țări. Sfintele slujbe au continuat a se săvârși în interiorul bisericilor, deși fără participarea poporului. Tainele Botezului și Cununiei și slujba înmormântării s-au putut face cu cel mult opt participanți, iar împărtășirea bolnavilor, la spital sau acasă, s-a realizat respectând regulamentele de ordine internă și alte reguli specifice (de ex.: preotul să poarte mască și încălțăminte de unică folosință și să folosească trusa pentru Sfânta Împărtășanie). Taina Sfântului Maslu de obște a fost temporar amânată, dar s-au înmulțit cererile pentru sănătate rostite în cadrul ecteniilor Sfintei Liturghii, la toate Sfintele Altare.

Liturghia nu a încetat niciodată în mănăstiri și biserici, deși credincioșii au fost nevoiți să stea în case. La finalul slujbelor, preoții au îngrădit poporul cu mila și ocrotirea Domnului Hristos, „Doctorul sufletelor și al trupurilor", citind „Rugăciunea" specială pe care însuși Preafericitul Părinte Patriarh Daniel a întocmit-o, text euhologic ce a depășit granițele Ortodoxiei românești, fiind folosită și de creștini

17 mai 2020, ora 17.27). Vezi şi „Rugăciunea“ citită de PF Patriarh, pe youtube.com/ watch?v=3ByJgeNvRM8 (accesat la 23 mai 2020, ora 18.45).

2. Biroul de Presă al Patriarhiei Române, „Îndemn la credință, echilibru și solidaritate", în: Ziarul Lumina, nr. 56 (4529), 23 martie 2020, p. 6, col. 1-2; Cancelaria Sfântului Sinod, „Noi măsuri privind slujbele și activitățile sociale bisericești“, în: Ziarul Lumina, nr. 57 (4530), 24 martie 2020, p. 3, col. 1-3. 
din alte Biserici Ortodoxe ${ }^{3}$. Cele șapte Laude, citirea neîntreruptă a Psaltirii și rugăciunea comună a întregii suflări creștinești din țară, de la ora 22.00, au creat un adevărat cor al grăirii poporului român cu Dumnezeu.

Credincioșii au fost îndemnați să își organizeze mai bine colțul lor de rugăciune și să urmărească Sfânta Liturghie și celelalte slujbe la TV și Radio Trinitas. Aceștia au avut la dispoziție rugăciuni postate pe site-urile ziarullumina.ro și basilica.ro, cărți de rugăciuni tipărite special pentru această perioadă sau chiar biblioteci digitale cu titluri bogate de carte duhovnicească și nu numai ${ }^{4}$.

„Stării de urgență“ i-a urmat „starea de alertă“, care continuă până în prezent, cu reguli ușor mai relaxate în perioada mai-septembrie ${ }^{5}$, dar iarăși în curs de înăsprire după 10 octombrie 2020. Viața și lucrarea Bisericii au continuat cu aceeași încordare hristică, dătătoare de energii vitale către fiii duhovnicești și au arătat aceeași seriozitate duhovnicească matură, în vederea respectării tuturor regulilor sanitare și sociale solicitate de autoritățile statului ${ }^{6}$.

3. A se vedea mărturia pr. dr. Jean-Claude LÂRCHET, care, în interviul acordat lui Jivko Panev, intitulat "Originea, natura și sensul pandemiei actuale" se exprimă astfel despre această rugăciune compusă de PF Patriarh Daniel: „În ce mă privește, îmi place şi o folosesc de multe ori pe zi, «Rugăciunea» alcătuită de Patriarhul Daniel al României, care este scurtă, simplă și completă". A se vedea pe https://orthodoxie.com)lorigine-la-nature-et-les-senses-de-la-pandemie-actuelle-une-inerview-de-jean-claude-larchet-par-orthodoxie-com/, accesat în 15 aprilie 2020, ora 20.15 .

4. ${ }^{* * *}$ „«Rugăciuni la vreme de boală și necaz» pe ziarullumina.ro“, în: Ziarul Lumina, nr. 56 (4529), 23 martie 2020, p. 7, col. 1-2; *** „Cărţi în format digital oferite gratuit de Editurile Patriarhiei Române“, în: Ziarul Lumina, nr. 70 (4543), 10 aprilie 2020, p. 3, col. 1-2; *** „«Rugăciuni la vreme de boală şi necaz» pentru pacienţii din centrele de tratare", în: Ziarul Lumina, nr. 59 (4532), 26 martie 2020, p. 6, col. 1-4.

5. Cancelaria Sfântului Sinod, „Îndrumări bisericești pentru starea de alertă", în: Ziarul Lumina, nr. 92 (4565), 18 mai 2020, p. 7, col. 1-3; Cancelaria Sfântului Sinod, „Noi îndrumări bisericești care se aplică din data de 17 iunie 2020“, în: Ziarul Lumi$n a$, nr. 113 (4586), 18 iunie 2020, p. 3, col. 1-3.

6. Fragment preluat - parțial - din alt studiu sistematic, redactat tot de semnatarul lucrării de față, sub titlul „Programe pastoral-misionare ale Bisericii Ortodoxe Române, în condiţii de pandemie" (25 pagini), care a fost oferit spre publicare în Anuarul Facultății de Teologie "Justinian Patriarhul" a Universității din București, în noiembrie 2020, acum aflat încă sub tipar. 
Pe aceleași coordonate generale, trasate de Sfânta Patriarhie, a evoluat și programul liturgic, duhovnicesc, pastoral-misionar, educaţional și social-filantropic din Arhiepiscopia Dunării de Jos pe toată perioada pandemiei, cu particularități și accente date de specificul zonei. Din inițiativa și sub coordonarea ÎPS Arhiepiscop dr. Casian al Dunării de Jos, eparhia noastră a dezvoltat și derulat programe adaptate situației generale din lume, pentru a susține slujirea și lucrarea clerului și pentru a ajuta, spiritual și material, pe cât mai multe dintre persoanele atinse de boală sau de efectele ei colaterale majore: singurătatea, frica, sărăcirea.

\section{Slujirrea liturgică, lucrarea pastorală, grija misionară și asistența social-filantropică, la Dunărea de Jos, în pandemie}

Și pentru creștinii ortodocși de la Dunărea de Jos, rugăciunea a fost temelia rezistenței în pandemie, iar lucrarea pastoral-misionar-socială a devenit mesajul luminos al Bisericii care, prin fapte bune a transmis concret, în casele a zeci de mii de creștini, căldura iubirii părintești a Domnului Hristos. Acest program complex al eparhiei, inițiat și coordonat de Centrul Eparhial, desfășurat prin protoierii, mănăstiri, parohii și așezăminte sociale, a fost concretizat prin prezență umană solidară și a fost materializat prin ajutoare care au acoperit trebuințele stringente ale multor oameni.

Programul eparhial din pandemie a adus și continuă să aducă un suport real pentru multe familii lovite de singurătate și pauperitate, a dat și dă siguranță duhovnicească multor persoane, pentru a-și depăși angoasa interioară, generată de spectrul pandemiei. Despre acest program complex, care a început în martie 2020 și care continuă încă (noiembrie 2020) se relatează în continuare.

\section{Program liturgic și duhovnicesc dens,} în biserici, în mănăstiri și în casele creștinilor

Experiența bimilenară a Bisericii arată că, la necazuri și încercări mari, creștinii au sporit rugăciunea și s-au întărit în credință. În contextul pandemic actual, sfințiții slujitori din Arhiepiscopia Dunării de Jos au înțeles cu adevărat dramatismul adânc al cererilor stăruitoare 
pe care odinioară, în vremuri de molime, înaintașii noștri le înălțau către Dumnezeu. Din acele strigăte, rostite cu lacrimi, au reieșit rugăciunile și ecteniile „la boli molipsitoare și ferirea de moarte năpraznică“, prin care preotul cere Domnului ca:

„(...) nu cu urgia Sa să ne mustre, nici cu mânia Sa să ne pedepsească pe noi, ci să Își aducă aminte că trup suntem și duh ce iese și nu se mai întoarce (...) să nu intre la judecată cu robii Săi, ci să caute spre fărădelegile noastre și să le șteargă (...) să tămăduiască durerile morții ce ne-au cuprins și pâraiele fărădelegii ce ne tulbură să le sece (...)"7.

Neîndoielnic, pe de o parte, pandemia a afectat viața liturgică a Bisericii, întrucât, în baza normelor sanitare, creștinii nu au mai putut intra, o vreme, în sfintele locașuri. Pe de altă parte însă, situația - grea și nemaintâlnită de generația noastră! - a motivat puternic săvârșirea sfintelor slujbe din cultul public, în special a Laudelor bisericești și a Sfintei Liturghii. Acestea nu au încetat, ci au căpătat intensitatea unui strigăt al poporului și al preoțimii, în rugăciune, către Domnul, la „vreme de molimă“. Ascultând cu fidelitate povățuirile duhovnicești și pastorale ale ÎPS Părinte Arhiepiscop Casian, preoții de la Dunărea de Jos au dat dovadă de echilibru duhovnicesc și de mare eroism liturgic, biruind disconfortul psihologic creat de faptul că, în partea a doua a Postului Mare, în Săptămâna Sfintelor Pătimiri, de Paști, în Săptămâna Luminată și în alte câteva săptămâni care au urmat au săvârșit slujbele în bisericile lipsite de credincioși. Ardoarea rugăciunii a biruit însingurarea și frica și a transmis, spre familiile creștinilor, semnalul: „Preotul nostru se roagă pentru noi! Să ne rugăm și noi împreună cu el și Dumnezeu nu ne va părăsi!“.

Potrivit solicitării Cancelariei Sfântului Sinod, în toată eparhia, în duminici și sărbători, la ora 12.00 , la toate bisericile s-au tras clopotele ${ }^{8}$, în semn de speranță și cu scopul de „a alunga răul", așa cum poporul nostru crede cu stăruință. Glossa antică „Laudo Deum verum, plebem vocco, congrego clerum, defunctos ploro, dissipo ventos, nimbum

7. Liturghier, Editura Institutului Biblic și de Misiune a Bisericii Ortodoxe Române, București, 2012, p. 457.

8. Cancelaria Sfântului Sinod, „Rugăciune comună la mijlocul zilei, în toată România“, preluare din volumul ÎPS Arhiepiscop dr. CASIAN AL DUNĂRII DE Jos, Rugăciune. Comuniune. Filantropie, Editura Arhiepiscopiei Dunării de Jos, Galați, 2020, p. 91. 
fiigo, festa decoro“ („Laud pe Dumnezeu Cel Adevărat, chem poporul, adun clerul, plâng morții, împrăștii vânturile, risipesc norii, împodobesc sărbătorile"), care arată rolul clopotului în cult și în viața socială a comunității, a fost completată, în situația de față, cu: „morbum protero et adduco sanitatem “ („alung boala și aduc sănătate") 9 .

Sfintele Taine care nu au putut fi amânate (Spovedania, Maslul, Botezul) s-au săvârșit cu respectarea normativelor trasate de autorități. În chip special trebuie subliniat faptul că, grație bunei sfătuiri a preoţilor de către ÎPS Părinte Casian ${ }^{10}$, pe teritoriul canonic al Eparhiei Dunării de Jos nu s-au înregistrat nici contestări izolate și niciun fel de mișcare de grup care să vizeze procedura liturgică a cuminecării cu lingurița. Drept urmare, în consonanță cu rânduielile canonico-liturgice ale Bisericii Ortodoxe, în Arhiepiscopia Dunării de Jos, în această perioadă extrem de dificilă, ritmul penitențial-euharistic al Postului Mare și-a menținut pulsul duhovnicesc la cote (aproape) normale.

Rugăciunea comunitară a fost consolidată puternic de rugăciunea personală, de acasă, pe care preoțimea și poporul au îmbrățișat-o cu și mai mare râvnă. A contat enorm exemplul personal al arhiepiscopului nostru, care, în fiecare seară, la ora 22.00 a plecat genunchii pentru toată suflarea creștină de la Dunărea de Jos. Capela reședinței arhiepiscopale a devenit, în fiecare seară, o vastă catedrală în care, prin intermediul mijloacelor moderne de comunicare, „au intrat" duhovnicește toți cei care au dorit să fie în comuniune de rugăciune cu ierarhul. Rugăciunea ÎPS Sale și cuvântul de învățătură transmise „live“ au fost o mângâiere și o încurajare mai presus de cuvinte pentru cei peste 20.000 de ucenici și fii duhovnicești consecvenți seară de seară pentru împreuna-rugăciune realizată prin conexiunea on-line. Având conștiință misionară, mare parte dintre participanţii la această rugăciune au înmulțit darul, trimițând și altor persoane îndemnul la rugăciune comună, împreună cu ÎPS Părinte Casian. Astfel se explică multiplicarea rugăciunii și binecuvântării ÎPS Arhiepiscop, în mediul virtual

9. Licență teologică-lingvistică a semnatarului studiului de față.

10. ÎPS Arhiepiscop dr. CASIAN AL DUNĂRII DE JOS, ,Îndrumări către slujitori sfinţiți şi credincioşii din Arhiepiscopia Dunării de Jos, în timp de pandemie", în: Rugăciune. Comuniune. Filantropie..., pp. 123-125; ÎPS Arhiepiscop dr. CASIAN AL DUNĂRII DE Jos, „Foarte important!“, în: Rugăciune. Comuniune. Filantropie..., pp. 171-172. 
care a devenit astfel un excelent spațiu misionar, spre 140-150.000 de persoane $(!)^{11}$ care au primit, seară de seară, semne duhovnicești de „bunăvestire" și bucurie, în vreme de tristețe și boală.

Deși a creat atât de multă emulație spre rugăciune și pace sufletească (cum niciun alt program misionar eparhial nu reușise până în acel moment!), stăruința și puterea pe care le-a arătat chiriarhul nostru în acea perioadă au fost puse, de către ÎPS Sa, pe seama darului lui Dumnezeu, care a lucrat inspirator, unificator și încurajator, pentru toți cei prinși în „vuietul rugăciunii“:

„Acesta este darul lui Dumnezeu! Lui să-I mulțumim! Nu noi suntem cauza rugăciunii de seară, în comun, de la paraclis, sau a rugăciunii pentru cei decedați din sâmbetele Postului Mare, a Sfântului Maslu din Catedrală, ori a Sfintei Liturghii, ci Domnul Iisus Hristos, Maica Domnului și toți sfinții. Desigur, fără chemarea și dragostea noastră, n-ar fi cu putință aceste stări de sănătate sufletească și de iubire frățească, prin care îndepărtăm frica de boală și obținem sănătate! ${ }^{12}$

Acest program a fost adoptat de mulți preoți și de foarte mulți dintre creștini, care au redescoperit dulceața rugăciunii „de aur", de la ora 22.00 până spre miezul nopții. Expun aici câteva ecouri ale acelor trăiri duhovnicești personale, exprimate prin scris și publicate în recentul volum al ÎPS Arhiepiscop Casian, intitulat „Rugăciune. Comuniune. Filantropie“:

11. Toate evenimentele din viața Arhiepiscopiei Dunării de Jos sunt vizualizate, zilnic, de zeci de mii de persoane. Până acum, "vârful" rating-ului a fost de 333.000 de vizualizări, numărul însumând și like-urile aferente! Statisticile arată că aproximativ 50 \% dintre persoanele care țin legătura cu Eparhia noastră, în acest fel, au vârste cuprinse între 25 și 55 de ani. Peste 32 \% sunt gălăţeni, cca $13 \%$ sunt brăileni, iar 7,6 \% locuiesc în București. Fii ai zonei aflați temporar în alte țări urmăresc consecvent site-ul și Facebook-ul Arhiepiscopiei, din: Italia (6,2\%), Marea Britanie $(2,3 \%)$, Germania $(2,1 \%)$, Spania $(1,8 \%)$. Această dispersie reflectă, pe de o parte legătura sufletească a fiilor Dunării de Jos cu țara și zona lor de baștină, iar pe de altă parte arată modul în care Eparhia și ÎPS Arhiepiscop Casian personal îşi manifestată grija și cultivă legătura acelor oameni cu obârșiile lor, în cel mai frumos și sfânt chip: rugăciunea şi binecuvântarea părintelui duhovnicesc pentru fiii săi duhovnicești. Detalii și la pr. Rareș BucuR, „Rugăciune, filantropie și comunicare“, în: Călăuză ortodoxă, XXX (2020), nr. 377, p. 29.

12. ÎPS Arhiepiscop dr. CASIAN AL DUNĂRII DE Jos, „Rugăciune, comuniune, filantropie“, în: Călăuză ortodoxă, XXX (2020), nr. 377, p. 14. 
„(...) am aranjat în sufragerie un colțișor de rugăciune format dintr-o icoană a Mântuitorului, una cu Mama noastră - Maica Domnului, cu sfinţii ocrotitori ai parohiei noastre și ai casei, primiți în dar la Cununia părinților și câte o icoană cu sfinții ale căror nume le purtăm. În fața acestui mic altar ne-am rugat zilnic și am trimis cererile noastre «Doctorului sufletelor și al trupurilor noastre»" (Elena Sandu, 22 ani, studentă la Facultatea de Litere a Universității din București, parohia Bucești, jud Galați).

„Chiar dacă mi-a fost greu să stau departe de biserica atât de dragă mie încă din copilărie, nu am vrut să mă dau bătut și am căutat, pe cât am putut, să respect tainele credinței mele: am ținut postul, am ascultat slujbele la radio, am aprins candela în fiecare zi și, cu cățuia cu cărbune și tămâie și cu lumânarea aprinsă în mână m-am rugat cât am putut pentru iertarea păcatelor și pentru binele acestei lumi" (Velu Bourceanu, parohia Cristești, jud. Galați).

„Știu că rugăciunea ascultată prin intermediul Internetului nu este deplină, însă în fiecare seară ne unim toți cei din familie și așteptăm cu nerăbdare să vină ora 22.00 , când putem să ascultăm rugăciunile Înaltpreasfinţitului Părinte Casian, asemenea unei adieri de vânt în arșița verii, rugăciuni la care intră în comuniune mii de credincioși din mediul online" (prof. de Religie Vasilica Mihalache, parohia Tudor Vladimirescu, jud, Galați).

„Fără biserică a fost greu, dar sunt convinsă că fiecare creștin și-a transformat casa într-o biserică“ (Andreea Cristina Bănică, parohia Movila Miresii, jud. Brăila) ${ }^{13}$.

Deci, în pandemie, sufletele oamenilor s-au reîmprospătat, s-au reconectat la Izvorul vieții lor, Domnul Dumnezeu, și-au întors căutările spre Maica Domnului și spre sfinți. Mulți creștini au renăscut duhovnicește și acest fapt este „binele din rău" și „lumina din întunericul" stării pe care întreaga lume a parcurs-o în perioada martie - mai 2020.

Pe temelia rugăciunii s-a așezat, așadar, întregul program misionar, pastoral, educațional și filantropic al Arhiepiscopiei noastre, din perioada pandemiei care, iată, se prelungește până la finalul anului 2020.

13. ÎPS Arhiepiscop dr. CASIAN AL DUNĂRII DE Jos, „Credincioși regăsirii și solidarității în Biserică“, în: Rugăciune. Comuniune. Filantropie..., pp. 407, 452-453, 455. 


\section{Conștientizarea, de către cler și popor, \\ a gravității situației și chemare continuă \\ la respectarea normativelor specifice emise de autorități}

$\mathrm{Nu}$ a fost uşor de explicat oamenilor că pericolul este real și mare. Mulți dintre creștini, derutaţi de mesajele insistente venite de pe site-uri obscure sau induși în eroare de discursul "de dreapta" și cu accente anarhice al unor persoane iresponsabile, au fost ispitiți să nu acorde nicio crezare gravității situației și să nu respecte măsurile luate de autoritățile civile și bisericești pentru diminuarea efectelor pandemiei.

Drept urmare, oamenii au adoptat trei atitudini, diferite. Cei mai mulți dintre creștini și-au asumat, cu responsabilitate, întreaga situație, respectând regulile și luptând pentru revenirea la normalitate. Unii s-au constituit în grupuscule de contestatari, care au avut atitudine reținută și chiar contrară tuturor rânduielilor civile și bisericești din această perioadă. Alții s-au claustrat în case sau în ei înșiși, devenind pradă sigură pentru diverse stări de criză interioară, uneori complicate sau chiar grave.

Astfel, încă de la începutul pandemiei, ÎPS Arhiepiscop Casian al Dunării de Jos a dat, preoților și credincioșilor, semnale corecte, concrete, bine dozate ca intensitate și clare ca mesaj, pentru ca toți păstoriții dintre fruntariile eparhiei să înțeleagă realitatea pericolului și să respecte întru totul regulile civile și rânduielile bisericești, menite să îi protejeze trupește și să îi ajute sufletește. Pentru credincioși, cuvântul de ordine a fost, mereu, „credință nestrămutată“ și "grija pentru aproapele și pentru sine“. Într-unul dintre primele sale mesaje adresate preoțimii și credincioșilor, ÎPS Sa accentua aceste două comandamente:

„(...) în încercări suntem capabili să ne întâlnim creștinește, în iubirea pentru cei mai triști și mai încercați, deoarece în ei trăiește Hristos! De aceea toți cei ce ne primesc în «cămara Mântuitorului», care este inima bună a fiecăruia dintre noi, sunt ca niște «icoane» luminoase în momentele triste pe care le traversăm. (...) Uniți în fața Altarului lui Hristos, din sfintele biserici, încălziți de dogoarea rugăciunilor sfințiţilor slujitori și ale evlavioșilor creștini ne îndreptăm, cuviincios, spre «altarul fratelui», așa cum ne-a învățat Sf. Ioan Gură de Aur, încă din secolul al IV-lea. Dar 
să nu uităm că Domnul Hristos oficiază «Liturghia» bunătăţii pe altarele inimilor noastre, de 2.000 de ani! ${ }^{\prime 14}$.

\section{Comunicare permanentă a Chiriarhului cu corpul clerical, pentru menținerea unității în Hristos și în Biserică și pentru susținerea disponibilităţii pastoral-liturgice și misionare}

Una dintre cele mai importante metode de a ține unitatea duhovnicească, dar și instituțională, în timpuri atât de fluide și instabile a fost comunicarea permanentă a chiriarhului cu preoțimea. Întrucât condițiile sanitare și regulamentele perioadei nu au permis întruniri în conferințe și nici măcar în grupuri mai mici, ÎPS Casian a apelat la cea mai eficientă, sigură și fără echivoc comunicare cu preoțimea, tradițională în viața Bisericii: scrisoarea pastorală. Pe parcursul întregii perioade martie-octombrie, mesajele scrise ale ÎPS Sale, adresate preoțimii, au răspuns și răspund punctual la întreaga problematică specifică, generată de situația pandemică; mesajele ÎPS Sale au adus și aduc preoților sfatul cel mai potrivit, la timpul când trebuința era / este cea mai mare!

Aceste texte, niște bijuterii epistolare în fapt, care cuprind o bogăție de învățături, sunt scrise cu har și au, totodată, un caracter extrem de practic, acoperind teme diverse, de la povăţuiri duhovnicești și sfătuire părintească până la îndrumări liturgice și pastoral-misionare, de la îndemnuri la lucrare social-filantropică până la chemarea la împreună-bucurie și prăznuire. Mai mulți preoți mi-au mărturisit emoția lor când au văzut că textele sunt redactate special „pentru sfințiţii slujitori", că au fost îndreptate către ei prin protoierii, pe grupurile de wattsupp și că, întotdeauna au venit la timpul optim. Unele dintre acestea sunt scrise "manu propria" de ierarh, detaliu care le sporește valoarea și denotă grija ÎPS Sale pentru preoți și dorul său de comuniune cu preoțimea și cu poporul dreptcredincios.

Dintre aceste mesaje, încă nepublicate, spicuiesc unele fragmente, ilustrative și mult-grăitoare.

14. ÎPS Arhiepiscop dr. CASIAN AL DUNĂRII DE Jos, „Îndemn de suflet", în: Călăuză ortodoxă, XXX (2020), nr. 375-376, p. 16. 
În Postul Mare, înainte de Duminica Sfintei Cruci, amintind că puterea purtării Crucii vine prin unitatea în Domnul Hristos, ÎPS Sa scria preoților:

"(...) Chiar şi acum, frații mei, când nu avem putința să stăm unul lângă altul trupește, a venit vremea să fim tot mai aproape sufletește unul lângă altul! Sufletește suntem toți astăzi uniți! Toți suntem cruce $(. . .)^{\prime 15}$.

Îndemnurile spre curaj și solidaritate au fost extrem de bine primite de "cei din linia întâi“, alături de medici, preoții:

"(...) Toți suntem împreună, cu multă încredere în mila, în iubirea și-n ajutorul lui Dumnezeu. Să fiți siguri: Domnul este acolo! Ne însoțește în toate împrejurările, ne apără și ne dă speranță! (...) Suntem împreună nu numai solidari, ci unul pentru altul, acum și în viitor! ${ }^{116}$.

Ca soluții de rezistență a familiei preoțești și a familiei creștine - în general - aflate în carantină, ierarhul nostru a propus mereu răbdarea, îngăduința reciprocă și slujirea hristică, a unuia pentru altul:

"(...) în familie soțul să slujească soției și soția soțului, copiii părinților și părinții copiilor, dascălii elevilor și studenților și viceversa, medicii bolnavilor și bolnavii medicilor și toți atât cât putem. Să ne slujim, să ne transmitem ştiri bune $(. . .)^{17}$.

Urmare primelor serii de decese cauzate, la nivel naţional, de pandemie, cu puțin timp înainte de Paști, în data de 3 aprilie 2020, ÎPS Sa scria preoților astfel:

"(...) Mare atenție la administrarea celor Sfinte (...) În mesaje fiți optimiști, din optimismul convingerilor creștine (...) Să ne pregătim, fraţii mei, pentru pastorația sufletelor afectate de decesul celor apropiaţi, în urma bolii Covid 19, în limitările impuse de starea de epidemie. Lumânările, pomelnicele, pachetele de ofrandă, dar mai ales încurajările personale ale preotului pot face minuni... Nu vă temeți! (...)“.

15. ÎPS Arhiepiscop dr. CASIAN AL DUNĂRII DE Jos, „Crucea este întotdeauna putere și biruință“, în: Rugăciune. Comuniune. Filantropie..., p. 127.

16. ÎPS Arhiepiscop dr. CASIAN AL DUNĂRII DE JoS, „Mesaj către persoanele aflate în carantină“, în: Rugăciune. Comuniune. Filantropie..., p. 91.

17. ÎPS Arhiepiscop dr. CASIAN AL DUNĂRII DE Jos, „Să ne slujim unii pe alții“, în: Rugăciune. Comuniune. Filantropie..., pp. 158-159. 
La începutului Postului Adormirii Maicii Domnului, în contextul ivirii semnalelor privind nedoritul dar previzionatul „val 2 “ al pandemiei, ierarhul oferea o serie de alte povățuiri, pentru protecția preoților și a credincioșilor, deopotrivă:

„La slujbele din afara sfântului locaș să respectăm distanțarea fizică și purtarea măștii de protecție! (...) să planificăm logic şi responsabil, pentru protecția credincioșilor și a noastră, spovedaniile în biserică, între slujbe, cu distanțare de 2 metri și purtarea obligatorie a măștii, și de către duhovnic, și de către penitent. Se recomandă, pe cât posibil, Împărtășirea imediat după Spovedanie, iar duminica și la sărbători, la sfârșitul slujbei, cu respectarea normelor cunoscute".

Unele dintre scrisorile pastorale au un adânc conținut teologic și duhovnicesc. În pregătirea sărbătorii Adormirii Maicii Domnului, în data de 13 august, preoții au fost chemați la prăznuire astfel:

„Maica Domnului ne întinde nu doar brațele, ci ea ne oferă «casa» inimii milostive, miloase și generoase, iertătoare și iubitoare! Ne cheamă înăuntru! Pe fiecare și pe toți. 0 primim? 0 acceptăm? Îi împlinim dorul și dorința? Haideți, cu toții, frați și surori! Haideți ACASĂ! Să intrăm! Fără sfială! Acolo este loc pentru fiecare, mic și mare, bun ori fără bunătate, drept ori păcătos! Lăsați-o pe Maica iertării, milei, comuniunii, vindecării de răni văzute și nevăzute, să ne vindece".

Iar în ajunul sărbătorii Nașterii Maicii Domnului, la 7 septemnbrie 2020, preoții de la Dunărea de Jos primeau următorul îndemn:

„(...) Începem anul spiritual cu nașterea celei ce ne ajută să renaștem la starea copilului nevinovat și încheiem cu mutarea la Cer, Sfânta Adormire a Mamei neadormite, în Cer și pe pământ. Nașterea Maicii Domnului naște «bucuria a toată lumea». Știm de ce! Să arătăm și semenilor! (...) Naşterea Maicii Domnului deculpabilizează firea căzută în păcat, înnoind-o, întinerind-o! Așadar, mare Taină a zilei sfinte! Fie ea așa, în noi, în familie, în enorie, între noi, și la orice început cu Dumnezeu! (...)".

Cândva, aceste epistole vor constitui subiectul unor analize mult mai atente, din partea unor cercetători care vor dori să știe cum a reușit generația noastră să depășească momentele de criză generate de pandemia cu SARS COV-2. Dacă atunci se va aprecia că poporul și preoțimea de la Dunărea de Jos au biruit cu demnitate umană și în credință creștină această mare încercare, concluzia va fi susținută și de acest efort epistolar al arhiepiscopului nostru, care a știut să își adune fiii 
duhovnicești și să păstreze unitatea de credință, de rugăciune și de făptuire de bine a clerului și poporului din eparhie.

\section{Aparatură și echipament medical oferite de Sfânta Arhiepiscopie spitalelor din județele Galați și Brăila}

Înțelegând limitele sistemului medical din zonă, greu încercat de numărul mare de cazuri de îmbolnăviri și motivat de dorința de a ajuta în special pe creștinii aflați la A.T.I., ÎPS Arhiepiscop Casian a inițiat o amplă campanie de susținere a spitalelor din zona Galați-Brăila. Urmând pilda ierarhului, care a oferit întregul său salariu pentru opera filantropică a eparhiei, preoții gălățeni și brăileni și mulți binefăcători cooptați în această campanie au donat părți importante din salariile lor pe lunile aprilie și mai. Aceste sume, gestionate riguros prin intermediul „Fondului special eparhial pentru acordarea de sprijin în perioada pandemiei cu virusul SARS COV-2“, au servit la susținerea acțiunilor filantropice inițiate și cordonate de eparhie ${ }^{18}$. Donaţiile au căpătat o semnificație aparte, în contextul în care bisericile și mănăstirile, neavând popor la slujbe, au întâmpinat și încă se confruntă cu dificultăți economice.

Unul dintre primele obiective ale Eparhiei l-a constituit, deci, dotarea spitalelor din Galați și Brăila, destinate tratării celor infectați de virusul SARS COV-2, cu două ventilatoare noi și moderne, de înaltă performanță, însoțite de echipamentele și subansamblele medicale adiacente. Donația către Spitalul Județean de Urgență din Brăila, constând într-un ventilator mecanic "Trilogy 100", marca „Philips", s-a făcut prin intermediul și cu contribuția financiară majoră a preoților din Protoieria Brăila (30 aprilie 2020) ${ }^{19}$. Donația către Spitalul de Urgență

18. Biroul de presă al Arhiepiscopiei Dunării de Jos, „Apel la solidaritate creștină. Ierarhul și clericii din Arhiepiscopia Dunării de Jos achiziționează aparatură medicală pentru spitalele din Galați, Brăila și Tecuci", în: Călăuză ortodoxă, XXX (2020), nr. 377, p. 28.

19. Costel CRÂNGAN, „Aparatură medicală de strictă necesitate donată de preoții brăileni", preluare de pe https://adevarul.ro/locale/braila/aparatura-medicala-stricta-necesitate-donata-preoti-spitalului-judetean-urgenta-braila-1_5eaad63b5163ec427149cc39/index.html (17 octombrie 2020, ora 12.55). 
„Sfântul Apostol Andrei“ din Galați, constând într-un ventilator „Trilogy Evo", însoțit de patru concentroare de oxigen „EverFlo“ și celelalte anexe s-a făcut prin contribuţia multor donatori, cooptaţi în campania „Donează pentru viață“, coordonată de Muzeul Istoriei Culturii și Spiritualității Creștine de la Dunărea de Jos (14 mai 2020) ${ }^{20}$.

Intervenţia și ajutorul Eparhiei au fost salutare, întrucât în acele două instituții medicale ventilatoarele se aflau în număr extrem de limitat și, unele, din generații tehnice depășite moral. Din aceste motive, exista riscul incapacității pentru a salva din ghearele bolii pe creștinii internați infectați cu virusul mortal

De asemenea, Eparhia a mediat și a contribuit financiar consistent pentru achiziționarea unui al treilea aparat, în parteneriat cu Universitatea „Dunărea de Jos“ din Galați și cu alte instituții reprezentative din zonă.

\section{Măști, combinezoane, dezinfectanţi și produse de igienă pentru spitalele din eparhie}

În condiții de pandemie, cu reguli sanitare extrem de precise, creștinii au fost solicitați să se apere împotriva oricărei posibile infectări, folosind substanțe cu rol dezinfectant și măști de protecție. După epuizarea, în scurtă vreme, a stocurilor disponibile la nivel național, a urmat o perioadă de panică, întrucât aceste materiale atât de importante pentru protejarea persoanei umane lipseau, iar comenzile făcute la diverși producători internaționali, întârziau. La îndemnul ÎPS Arhiepiscop Casian, atelierele de croitorie din mănăstirile eparhiei au început să confecționeze măști și combinezoane medicale. Zeci de mii de astfel de exemplare de materiale de protecție, lucrate de mâinile călugărițelor de la mănăstiri din eparhie ${ }^{21}$ ori achiziționate de la furni-

20. Vasile Robert NiCHIFOR, „Muzeul Arhiepiscopiei Dunării de Jos vine în sprijnul celor afectaţi de pandemie", în: Ziarul Lumina, nr. 91 (4564), 15 mai 2020, p. 6, col. 2-3; Dan PAIC, „Galați: Muzeul eparhial a donat Spitalului Clinic de Urgență un ventilator mecanic", preluare de pe https://www.agerpres.ro/social/2020/05/15/ galati-muzeul-eparhial-a-donat-spitalului-clinic-judetean-de-urgenta-un-ventilator-mecanic--506342 (17 octombrie 2020, ora 12.50).

21. V. R. NECHIFOR, „Noi acțiuni de sprijinire a spitalelor și a persoanelor aflate în izolare (Argeș, Galați, Caransebeș)“, în: Ziarul Lumina, nr. 63 (4536), 1 aprilie 
zori civili au ajuns, gratuit, în special la personalul medical din spitale (cel mai expus îmbolnăvirilor) și la creștini nevoiași din toate colțurile țării. Grija părintească a ÎPS Chiriarh față de preoțime s-a dovedit, încă o dată, extrem de vie, dar și de practică: în prima parte a lunii aprilie, toți preoții din epahie au primit din partea ÎPS Sale, gratuit, seturi de măști și de mănuși chirurgicale, pentru protecție împotriva infectării. Deodată cu darul, a oferit, stăruitor, sfatul „protejați-vă cu măști“, cât și sugestia ca gestul ÎPS Sale să fie urmat și multiplicat tot de atâtea ori câți slujitori sfințiţi are eparhia noastră:

„La binefacerea rugăciunii și comunicării la distanță ne gândim că cel mai util dintre darurile pascale, după Sfânta Lumină, este «0 mască de protecție într-un plic!» - noul nostru program filantropic pentru credincioși. Sugerați-ne cum și unde putem confecționa mai multe! Toate atelierele din mănăstirile noastre vor începe de mâine confecționarea de măști. Pânza albă de Florii să o convertim în protecția noastră și a fraților noștri, față de virus!" ${ }^{\prime 22}$.

Îndemnul, transpus în faptă de preoți, a devenit un program misionar-filantropic eparhial coerent, în condițiile crizei de măști din luna aprilie.

Tot în acest context, dorind să fructifice buna relație inter-instituțională și umană a Eparhiei cu Universitatea „Dunărea de Jos“, ierarhul nostru a chemat pe președintele senatului universitar, dl prof. univ. dr. ing. Cătălin Fetecău, la un proiect comun, de mare impact: confecționarea de viziere ${ }^{23}$ pentru personalul medical din spitale. Universitatea a pus la dispoziție laboratoarele și specialiștii, iar Eparhia

2020, p. 7, col. 1-3; V.R. NECHIFOR, „Biserica susţine în continuare cadrele medicale și persoanele aflate în dificultate (București, Argeș, Galați, Slobozia, Caransebeș)“, în: Ziarul Lumina, nr. 68 (4541), 8 aprilie 2020, p. 7, col. 1-3.

22. ÎPS Arhiepiscop dr. CASIAN AL DUNĂRII DE Jos, „Iubiților", în: Rugăciune. Comuniune. Filantropie..., p. 160.

23. Pr. R. BuCUR, „Arhiepiscopia Dunării de Jos sprijină cadrele medicale în lupta cu coronavirusul", în: Ziarul Lumina, nr. 61 (4534), 30 martie 2020, p. 6, col. 1-4 publicat și în: Călăuză ortodoxă, XXX (2020), nr. 377, p. 27; V. R. NECHIFOR, „Ajutorarea semenilor în vremuri de pandemie (București, Târgoviște, Argeș, Galați-Brăila, Slobozia)“, în: Ziarul Lumina, nr. 83 (4556), 5 mai 2020, p. 7, col. 1-4; V. R. NECHIFor, „Sprijin material și moral pentru persoanele afectate de pandemie. Arhiepiscopia Dunării de Jos", în: Ziarul Lumina, nr. 88 (4561), 12 mai 2020, p. 7, col. 2-4. 
a susținut financiar achiziționarea de folie specială și subansamble necesare. Spitalele din zonă au primit viziere, pentru protecția personalului medical; la solicitarea PS Veniamin, Episcopul Basarabiei de Sud, viziere produse prin cooperarea amintită au ajuns și în spitalele de peste Prut, unde se resimțea mare nevoie. Din acest proiect comun, la inițiativa rectorului, dl prof. dr. ing. Lucian Puiu Georgescu, s-a născut al doilea proiect: în laboratoarele Universității „Dunărea de Jos“ se produc acum două biocide - omologate deja de autoritatea națională de resort - și alte substanțe dezinfectante, anti-COVID. Produsele respective sunt astăzi utilizate în țară și în Europa.

Și la acest capitol, programele eparhiei au avut un caracter didactic: credincioșii au fost mereu îndemnați să aibă grijă de igiena personală și să folosească, pentru aceasta, materiale specifice. Sfatul a fost dublat de faptă. Programul eparhial peren „Ne înnoim de Sfintele Paști!“24 a fost, anul acesta, transformat într-o campanie generală, în toată eparhia, de curățenie și igienă. Arhiepiscopia a achiziționat detergenți, săpun, dezinfectanți și alte produse specifice, care au ajuns, ca daruri, în casele creștinilor din cătune și sate, în grădinițe și școli, în dispensarele sătești și în spitale ${ }^{25}$, în centrele sociale ale parohiilor și în biserici, dar, mai cu seamă, în „Centrele de izolare“, prin care au trecut mii de persoane susceptibile a fi infectate.

\section{Alimente și haine pentru creștinii cu mari trebuințe}

În această perioadă, una dintre trebuințele stringente ale celor aflați în carantină, în autoizolare sau în deficit financiar a fost lipsa de hrană. Și pe această coordonată, vitală, parohiile, mănăstirile, centrele sociale parohiale din eparhie s-au transformat în „betleemuri“ - „case ale pâinii“! Din luna martie și până în prezent, zeci de mii de persoane au primit hrană caldă și alimente fundamentale. Primele care au fost susținute consistent, de către Eparhie, au fost centrele cu persoane în

24. ÎPS Arhiepiscop dr. CASIAN AL DUNĂRII DE JoS, „Rugăciune, comuniune, filantropie", în: Călăuză ortodoxă, XXX (2020), nr. 377, p. 16.

25. Pr. R. BUCUR, „Material de igienă pentru personalul medical și auxiliar din spitale“, în: Călăuză ortodoxă, XXX (2020), nr. 375-376, p. 19. 
carantină. Centrul de carantină de la Galați a primit, gratuit, din partea Centrului Eparhial, mai mult de două luni, pentru persoanele aflate temporar acolo, pachete cu hrană caldă. Centrul de la Brăila a fost susținut constant de către Mănăstirea „Sfântul Pantelimon“ de la Lacu Sărat și alte parohii din municipiu ${ }^{26}$, iar centrul de la Tecuci de către protoierie și parohiile din zonă.

Trecând peste condițiile economice extrem de dificile, cele 25 de cantine parohiale din cuprinsul eparhiei au săvârșit o lucrare de impact major în popor: asigurarea hranei pentru persoane aflate la limita subzistenței. Zilnic, între 700 și 800 de persoane (dintre care peste 220 de copii) primesc hrană caldă de la cantinele parohiale din orașele Galați și Brăila. În paralel, celelalte parohii, prin centrele sociale, cu implicarea comitetelor de doamne, au realizat continuu acțiuni filantropice care au vizat pe cei sărmani din cuprinsul enoriilor.

Pe lângă alimente, eparhia, mănăstirile și parohiile au donat spitalelor și diverselor persoane aflate în impas, și alte obiecte necesare: lenjerii, haine, încălțăminte. Toate au fost oferite din dragoste creștină, de către parohii, mănăstiri, fundații, așezăminte sociale ${ }^{27}$.

26. *** „Sprijin pentru persoanele aflate în carantină“, în: Călăuză ortodoxă, XXX (2020), nr. 375-376, p. 22 (preluare de pe www.edj.ro).

27. V. R. NECHIFOR, „Acţiuni social-filantropice în Arhiepscopia Dunării de Jos“, în: Ziarul Lumina, nr. 58 (4531), 25 martie 2020, p. 3, col. 1-3; Pr. R. BucuR, „Ajutor pentru persoanele în carantină, de la Mănăstirea Lacu Sărat", în: Ziarul Lumina, nr. 59 (4532), 26 martie 2020, p. 3, col. 1-4; Pr. R. BuCUR, „Daruri oferite mamelor și copiilor de la Maternitatea «Buna Vestire» din Galați“, în: Ziarul Lumina, nr. 60 (4533), 27 martie 2020, p. 6, col. 1-4; V.R. NECHIFOR, „Eparhiile continuă sprijinirea instituţiilor medicale și a persoanelor aflate în situaţii dificile (București, Constanța, Argeș, Galați), în: Ziarul Lumina, nr. 64 (4537), 2 aprilie 2020, p. 7, col. 1-4; Andrei BuTU, „Eparhiile continuă și intensifică acțiunile de ajutor umanitar (Cluj, Buzău, Galați, Slobozia)“, în: Ziarul Lumina, nr. 66 (4539), 6 aprilie 2020, p. 6, col. 1-3; A. BuTU, „Noi acțiuni filantropice în Mitropolia Munteniei și Dobrogei (București, Constanța, Târgoviște, Argeș, Galați, Slobozia)“, în: Ziarul Lumina, nr. 67 (4540), 7 aprilie 2020, p. 7, col. 1-4; A. BuTU, „Arhiepiscopia Dunării de Jos, alături de persoanele nevoiașe“, în: Ziarul Lumina, nr. 69 (4542), 9 aprilie 2020, p. 6, col. 1-4; A. BUTU, „Acțiunile de sprijin umanitar continuă în eparhii (București, Galați, Slobozia)“, Ziarul Lumina, nr. 70 (4543), 10 aprilie 2020, p. 6, col. 1-3; V. R. NECHIFOR, „Intensificarea filantropiei în eparhii din Muntenia și Dobrogea (Târgoviște, Constanța, Galați, Slobozia)“, în: Ziarul Lumina, nr. 73 (4546), 15 aprilie 2020, p. 7, col. 1-3; V. R. NECHIFoR, „Acțiunile filan- 


\section{Donaţii de sânge}

Criza din spitale, creată de mulțimea cazurilor de îmbolnăviri, inclusiv din rândul personalului medical, s-a acutizat prin lipsa de sânge pentru transfuzii, situație care paralizează orice posibilitate de ajutor și tratament. Știind acest lucru, ÎPS Arhiepiscop Casian, în 16 iulie 2020 a trimis preoților un apel mobilizant, pentru a coopta donatori de sânge din parohii:

„(...) 0 rugăminte acum. Nu stăm bine cu plasma la spitale. Patriarhia a reluat programul cunoscut «0 picătură de sânge salvează o viață!». (...) Vă rog și vă solicit să sensibilizați donatorii, evident cu respectarea normelor de donare și de pandemie (...) Ne programăm și oferim ceea ce Domnul, Biserica Sa și conștiința noastră părintească și devotamentul misionar-pastoral ne solicită. Am toată încredințarea în buna organizare, din toate parohiile municipiului, a acestei necesare, foarte urgente, profund creștinești și filantropice lucrări (...) ${ }^{\text {“2828 }}$.

Urmare apelului ÎPS Sale, în Arhiepiscopia Dunării de Jos s-au organizat mai multe serii de donare de sânge. Cu protoiereii și preoții în frunte, grupe de credincioși din multe parohii, respectând condițiile impuse de situație, s-au prezentat la Centrele de transfuzii din Galați și Brăila. Demne de menționat sunt acțiunile de donare la care au par-

tropice din eparhii continuă în perioada pascală (București, Buzău, Galaţi)", în: Ziarul Lumina, nr. 75 (4548), 22 aprilie 2020, p. 3, col. 1-4; V. R. NECHIFOR, „Ajutorarea semenilor continuă în perioada pascală (București, Argeș, Galați-Brăila)", în: Ziarul Lumina, nr. 79 (4552), 28 aprilie 2020, p. 6, col. 1-4; V. R. NECHIFOR, „Noi campanii de ajutorare a persoanelor vulnerabile, în Patriarhia Română (București, Târgoviște, Argeș, Brăila)", în: Ziarul Lumina, nr. 80 (4553), 29 aprilie 2020, p. 7, col. 1-4; V. R. NECHIFOR, „Continuarea filantropiei în eparhiile din Mitropolia Munteniei și Dobrogei (București, Galați-Brăila, Slobozia)", în: Ziarul Lumina, nr. 81 (4554), 30 aprilie 2020, p. 6, col. 1-3; V. R. NECHIFOR, „Fapte concrete de ajutorare şi responsabilitate socială, în vremuri de pandemie (București, Constanța, Galați, Slobozia)", în: Ziarul Lumina, nr. 82 (4555), 4 mai 2020, p. 6, col. 1-3; V. R. NECHIFOR, „Ajutorarea semenilor continuă în Mitropolia Munteniei și Dobrogei (București, Galați, Slobozia)“, în: Ziarul Lumina, nr. 85 (4558), 7 mai 2020, p. 3, col. 1-3; V. R. NicHIFoR, „Responsabilitate şi implicare socială în comunități sărace (București, Galați-Tecuci, Ialomița)", în: Ziarul Lumina, nr. 90 (4563), 14 mai 2020, p. 7, col. 1-4.

28. ÎPS Arhiepiscop dr. CASIAN AL DUNĂRII DE Jos, „Iubiți Părinți", mesaj din 16 iulie 2020, preluat fragmentar de pe grupul de whatsapp al Cercului misionar nr 3 al Protoieriei Galaţi. 
ticipat voluntari din Protoieriile: Tecuci (22 februarie, 16 iulie $^{29}, 26$ august, 6 octombrie), Galați (20 iulie și 3 august) ${ }^{30}$, Brăila (27 august), Însurăței (17 septembrie), Nicorești (24 septembrie) ${ }^{31}$, Făurei (22 septembrie). Acțiunile au fost extrem de bine receptate de presă $\breve{a s}^{32}$ și de opinia publică.

Din martie și până la jumătatea lui octombrie 2020 au donat sânge cca. 450 de voluntari din parohiile eparhiei. Aceste campanii organizate de Arhiepiscopie au reechilibrat situația crizei de plasmă din spitalele din zonă și a dat speranță de viață multor bolnavi.

\section{Continuitate la Ora de Religie.}

Tablete pentru elevi și profesori din școli și licee

Criza creată de pandemie a afectat puternic și sistemul de învățământ. La toate nivelurile, cursurile nu s-au mai putut desfășura în sălile de clasă sau în amfiteatre, ci au trecut în format on-line ${ }^{33}$. Utilizând însă sistemele moderne de comunicare cu școlile, liceele, universități-

29. Pr. R. BucuR, „Preoți și credincioşi din protopopiatul Tecuci au donat sânge la Galați", în: Ziarul Lumina, nr. 134 (4607), 17 iulie 2020, p. 3, col. 1-2.

30. Pr. R. BucuR, „Preoții şi credincioșii gălățeni au donat sânge din nou“, în: Ziarul Lumina, nr. 147 (4620), 5 august 2020, p. 6, col. 1-3.

31. Pr. R. BucuR, "Credincioși din Protopopiatul Nicorești au donat sânge la Galați", în: Ziarul Lumina, nr. 184 (4657), 25 septembrie 2020, p. 3, col. 1-3.

32. De exemplu: Dorina NovAC, „Zeci de preoți și credincioși voluntari au donat sânge la Galaţi", în: Viața medicală din 16 iulie 2020 (preluare de pe https:// www.viata-medicala.ro/stiri/zeci-de-preoti-si-credinciosi-voluntari-au-donat-sange-la-galati-17697, 16 octombrie 2020, ora 20.10); D. PAIC, „30 de persoane de la Tecuci și Nicorești au donat sânge, la iniţiativa Arhiepiscopiei Dunării de Jos" (preluare de pe www.agerpress.ro, 16 octombrie 2020, ora 20.15); Ștefan ToTORCEA, „În 2020, Arhiepiscopia Dunării de Jos a mobilizat sute de donatori de sânge" (preluare de pe https://basilica.ro/90-de-voluntari-au-donat-sange-in-arhiepiscopia-dunarii-de-jos-in-2020-eparhia-a-mobilizat-sute-de-donatori/,16 octombrie 2020, ora 20.20).

33. Alina RoTARU, „Cum le explicăm copiilor noua «normalitate» de la şcoală sau grădiniță“, în: Ziarul Lumina, nr. 175 (4648), 14 septembrie 2020, p. 13, col. 1-4; Dana NiSTOR, „Şcoala în pandemie. Sfaturi pentru profesori și părinți“, în: Ziarul Lumina, nr. 178 (4651), 17 septembrie 2020, p. 12, col. 1-3; pr. prof. dr. Ioan C. TEŞU, „Relația părinților cu tehnologia, tipar în educația copiilor", Lumina de Duminică, nr. 38 (766), 20 septembrie 2020, p. 5, col. 1-5. 
le și profesorii lor, elevii din învățământul preuniversitar și studenții și-au continuat programul educațional.

În primele săptămâni de la instaurarea carantinei, copiii și tinerii au putut să își continuie drumul prin tainele credinței, participând la programul „Ora de Religie“, transmis de către TV Trinitas, prin intermediul unor grile speciale.

Sensibilă la trebuințele copiilor și tinerilor fără posibilități materiale, Biserica Ortodoxă Română, la solicitarea Ministerului Educaţiei, a inițiat o campanie națională de susținere a procesului de modernizare a învățământului din România. În această campanie s-a implicat, extrem de activ, și Arhiepiscopia Dunării de Jos. Din fonduri proprii sau prin parteneriat cu diverse instituții mari sau cu aportul unor sponsori, eparhia noastră desfășoară, din luna mai și până acum, un program specific, de susținere a elevilor și chiar a profesorilor din zone defavorizate sau aflați în situații economice modeste, constând în oferirea de tablete ${ }^{34}$. Psihopedagogii susțin că, prin forma on-line de comunicare, actul didactic își pierde cel puțin 30-40 \% din eficiență, iar conexiunea interumană - de asemenea. Cu toate acestea, tabletele dau totuși tinerilor șansa de a se conecta la programele educaţionale care, în această perioadă, li se furnizează on-line ${ }^{35}$. Pentru studenți, aceste daruri specifice generației lor, oferă posibilitatea participării la cursuri și seminarii, a consultării unor biblioteci virtuale, enciclopedii on-line sau a unor baze de date științifice și chiar șansa menținerii unei minime legături de comunicare intercolegială.

34. V. R. NECHIFOR, „Acțiunile de sprijinire a elevilor și a persoanelor vulnerabile continuă", în: Ziarul Lumina, nr. 89 (4562), 13 mai 2020, p. 6, col. 1-4; V. R. NECHIFOR, „Sprijinirea persoanelor vulnerabile continuă în timpul stării de alertă. Arhiepiscopia Dunării de Jos“, în: Ziarul Lumina, nr. 93 (4566), 19 mai 2020, p. 6, col. 3-4; V. R. NECHIFOR, „Tablete pentru elevi și ajutoare pentru săraci în vreme de pandemie. Arhiepiscopia Dunării de Jos", în: Ziarul Lumina, nr. 96 (4569), 22 mai 2020, p. 3, col. 1-3; V. R. NECHIFOR, „Noi acțiuni de sprijinire a elevilor și persoanelor vulnerabile în eparhii“, în: Ziarul Lumina, nr. 99 (4572), 27 mai 2020, p. 7, col. 1-3; A. BUTU, „Filantropie în județe din Muntenia, Dobrogea și Oltenia. Galați", în: Ziarul Lumina, nr. 103 (4576), 3 iunie 2020, p. 7, col. 2-4; pr. R. BUCUR, „Tablete oferite elevilor pentru noul an școlar", în: Ziarul Lumina, nr. 175 (4648), 14 septembrie 2020, p. 7, col. 1-4.

35. A se vedea articolul prof. Silvia FuLAȘ, „Experiența predării orei de Religie în contextul actual", în: Ziarul Lumina, nr. 130 (4603), 13 iulie 2020, p. 12, col. 1-3. 
Prima etapă a proiectului a constat în oferirea, de către Eparhie, a 350 de tablete, unor elevi cu posibilități materiale reduse. A doua etapă continuă prin inițiativele protoieriilor și parohiilor, care, la nivelul teritoriilor lor identifică anumite cazuri de copii și tineri aflați în dificultate, procură aparatele electronice și le oferă celor care au trebuinţă de ele.

\section{Program dens - didactic, duhovnicesc și misionar - pentru elevii seminariști}

Așa cum s-a întâmplat și cu celelalte licee din țară, și viața Seminarului Teologic a fost afectată de pandemie: cursurile la clasă au fost sistate, elevii au fost trimiși acasă, iar profesorii au fost nevoiți să își continuie activitatea predând orele on-line, prin intermediul platformelor didactice. Adresându-li-se printr-un cuvânt părintesc special ${ }^{36}$, în amintirea ceasurilor de rugăciune de seară - „murmur ceresc (...) în Capela Seminarului «Sfântul Apostol Andrei și Sfântul Ierarh Nectarie»" - ÎPS Arhiepiscop Casian propunea seminariștilor un program spiritual pentru perioada de claustrare, știut fiind cât de greu suportă tinerii limitarea libertății de mișcare și de relaționare. Din acest program, subliniez:

- invitația de a participa, zilnic, de la ora 22.00 , la rugăciunea pe care ÎPS Sa o făcea în capela reședinței arhiepiscopale și care se transmitea în direct, seară de seară;

- chemarea ca fiecare elev să își organizeze „un colțişor de rugăciune, de meditație, o microcatapeteasmă“;

- sugestia ca zilnic, tinerii să aibă lecturi cu subiecte „pline de speranță, de tinerețe, de curaj, de lumină, de frumusețe, de iubire de Dumnezeu, de popor, de țară, de lumea în care ne este dat să trăim";

- sfatul ca elevii din clasele a XII-a să se pregătească temeinic pentru examenele de bacalaureat, utilizând chiar și mijloacele virtuale pentru a-și „îmbogăţi cunoștințele și bunele deprinderi“;

- îndemnul de a transmite "vești bune" bunicilor, bolnavilor și colegilor de generație și de a-și simți, deși claustrați, „libertatea interioară“.

36. ÎPS Arhiepiscop dr. CASIAN AL DUNĂRII DE Jos, „Îndemn către elevii seminariști“, în: Rugăciune. Comuniune. Filantropie..., pp. 129-130. 
Beneficiind de aceste generoase și atât de folositoare povețe, elevii seminariști au putut să depășească acea perioadă, aplicând în viața lor ceea ce îi sfătuise Părintele lor Arhiepiscop. Mulți dintre ei au fost fideli rugători, în comuniune cu ÎPS Sa, seara la ora 22.00.

Toți au participat la cursurile on-line și la atelierele de lucru la care i-au chemat profesorii. Unii dintre ei (cei majori) au găsit forme să se implice în viața parohiilor lor, participând la slujbe și cântând la strană, ori implicându-se, ca voluntari, în acțiunile pastoral-misionare și filantropice desfășurate de preoți. Alții au fost de folos familiilor lor, împlinind diverse atribuţiuni pentru rezolvarea treburilor din case și gosodării. Important de știut: niciun elev seminarist nu s-a îmbolnăvit! Și, la fel de importamt de știut este faptul că seminariștii care au finalizat clasa XII-a au devenit, în mare majoritate, studenți la Facultățile și specializările pe care le-au vizat.

În legătură cu implicările lor din vremea pandemiei, imediat după ieșirea din carantină, am realizat un sondaj, prin care am aflat cum au reușit să fie harnici la studiu și buni misionari în familii și parohii, totodată. Dintre opiniile lor, citez câteva, semnificative:

„De-abia acum realizăm ce multă nevoie avem unii de alții. Abia acum am realizat cât de mult ar fi trebuit să prețuim libertatea pe care am avut-o! În ceea ce privește mersul la biserică (...) mă uitam din strană cum în sfântul locaș nu era nimeni... " (Daniel Balașa, clasa a XII-a).

„Majoritatea oamenilor am reuşit să ne regăsim sinele, să ne răspundem unor întrebări proprii, la care ori nu am avut timp, ori din alte motive nu am avut acum să găsim un răspuns. Cât despre separarea nedorită de casa lui Dumnezeu, acesta a fost un imbold să ne apropiem mai mult de Dumnezeu!" (Cosmin Ioniță, clasa a XII-a).

„În tot timpul cât am fost obligați să stăm în case, eu am fost un privilegiat. Mulțumesc lui Dumnezeu că, dascăl fiind la biserica din satul meu, am avut voie să merg la biserică. Însă, cu toate că aveam voie, aveam un sentiment ciudat: era sinistru să văd cât de singură este biserica fără credincioși! Am profitat de acest lucru și, alături de preoți, m-am rugat pentru sănătatea tuturor și pentru reîntoarcerea păcii în lume" (Ioan Petru Mitu, clasa a XII-a).

„Pe perioada pandemiei am stat toți în case. Lumea a rămas în loc șase luni! Suferința sufleteasca a lăsat răni adânci în sufletele multora. Legătura cea mai importantă, a omului cu Biserica, a părut a fi ruptă...Anul acesta, 
pe lisus Hristos nu L-am văzut înviind! Sărbătoarea pascală a fost sumbră, a fost în alb și negru..." (Andrei Dragoș Florea, clasa a XII-a).

"În timpul cât am fost obligați de situație să fim distanţaţi, a trebuit să ne transformăm propriile case în paraclise. Seara ne rugam împreună cu ÎPS Părinte Arhiepiscop Casian, on-line. Când ni s-a permis, am revenit în biserici și am ajutat după putere, împărțind creștinilor Sfânta Lumină, pasca. Fiind astfel de folos Bisericii mult încercate, m-am simţit ca un stâlp al bisericii din parohia mea! Mi-a fost dor de colegi, de profesori, de școală! Ne-a ajutat Dumnezeu și am reușit să ne reîntâlnim“" (Iulian Țopea, clasa a XII-a).

„Consider că Biserica a rezistat în carantină și a depășit cu bine această perioadă, în care eu m-am simţit mult mai aproape de ea, pentru că am văzut cu adevărat ce înseamnă lipsa ei în viața mea! Am fost voluntar la slujbe. Când am împărțit Sfânta Lumină am putut vedea în ochii oamenilor, pe de o parte durere pentru că nu pot veni la biserică, iar pe de altă parte o bucurie nemăsurată. Acum cred cu adevărat că oamenii nu pot sta departe de Biserică, indiferent de condițiile din jur" (Laurenţiu Stoian, clasa a XII-a).

"Casele noastre au devenit mici altare, unde am înălțat - spre mângâierea sufletelor - rugăciuni de mulțumire Mântuitorului Hristos. El a fost și este scăparea noastră! Această perioadă a fost și este o mare lecție de viață, pentru noi toți!“ (Ciprian Ghiorghiță, clasa a XII-a).

„«Pandemie», un cuvânt care a făcut din noi alți oameni... Ne-a adus doar «Stați în casă!» ori «Stați departe de Biserică!». Această distanțare impusă m-a făcut totuși să înţeleg și să apreciez mai mult ceea ce aveam mai înainte și cât de bine ne era, de parcă am fi stat cu capul pe pieptul lui Hristos!" (Viorel Ionuț Gurgu, clasa a XII-a).

„Pentru mine, perioada pandemiei, a fost o vreme de liniște, deoarece mi-am petrecut mai mult timp cu familia. Am avut zăbava de a mă ruga și de a mă apropia de Dumnezeu, mult mai mult. Am avut nespusa bucurie de a fi aleasă de părintele paroh și duhovnicul meu, totodată, să fiu voluntar în parohie, în perioada pascală. Împreună cu părintele, am împărțit salcia, pasca și agheasma enoriașilor din parohie. Iar în noaptea de Înviere am participat la slujbă, ajutând pe părintele: am susținut cântarea la strană" (Teodora Cristina Costea, absolventă iunie 2020) ${ }^{37}$.

37. Sondajul a fost realizat de semnatarul studiului de față, în zilele de 13 și 14 octombrie 2020. 


\section{Implicarea misionară a studenților teologi gălățeni}

Ca și colegii lor din țară și din toată Europa, studenţii teologi gălățeni şi-au continuat cursurile, în condiţii speciale, prin intermediul platformelor de comunicare on-line („Google Classroom“, „Zoom“, „,Moodle“, „Cisco“ ș.a.) sau, în special, după 1 mai pe platforma pe care le-a pus-o la dispoziție, gratuit, Universitatea „Dunărea de Jos“ din Galaţi: „Microsoft Teams". Aceste programe informatice au ajutat ca procesul de învățământ să nu se întrerupă și au susținut desfășurarea examenelor de evaluare din sesiunea iunie 2020 și organizarea/desfășurarea examenelor de susținere a licențelor și dizertațiilor, cât și a examenelor de admitere, sesiunile iulie și septembrie 2020.

Deși cursurile nu s-au putut face „față către față“, înțelegând consecințele dureroase pe care le aduc, unei mari părți a populației, izolarea fizică, lipsurile materiale și, îndeosebi, lipsa unei susțineri duhovnicești, studenții Departamentului Teologic din cadrul Facultății de Istorie, Filozofie și Teologie a Universității „Dunărea de Jos“ au susţinut o amplă campanie de voluntariat, care a început în data de 11 martie a.c. și a continuat până la jumătatea lunii iunie 2020. Proiectul a fost inițiat de ÎPS Arhiepiscop dr. Casian al Dunării de Jos, care, în cadrul unui comandament, la Centrul Eparhial, a dispus organizarea unui „Comitet de inițiativă“, alcătuit din studenți și masteranzi, teologi și nu numai. Primele acțiuni s-au derulat în perioada 16-31 martie, în parteneriat cu Prefectura Galați și cu Protoieria Galați, studenții fiind chemați să actualizeze baza de date cu persoanele vârstnice și vulnerabile din municipiul Galați. Prin sutele de telefoane pe care le-au dat, studenții au luat legătura cu aceste persoane, încurajându-le și notând trebuințele lor imediate. Apoi parohiile din municipiul Galați au organizat acțiuni umanitare punctuale, din echipele de voluntari făcând parte și studenți teologi.

Într-o a doua etapă (1-19 aprilie), studenții au răspuns la apelurile Centrului Eparhial Galați, fiind de mare ajutor la pregătirea pachetelor cu alimente și materiale pentru dezinfectare și curățenie și ducerea acestora la centrele de carantină și la alți beneficiari. După sărbătoarea Floriilor, tinerii au ajutat la pregătirea coșurilor pe care Sfânta Arhiepiscopie a Dunării de Jos le-a oferit unor instituții aflate 
în prima linie a luptei cu pandemia: spitale, unități de armată, poliție și jandarmi. În coșuri s-au aflat și icoane ale sfinților vindecători și ale altor sfinți, zugrăvite de studenţii de la specializarea „Artă Sacră“, care au fost oferite acelor instituții de către Chiriarhul Dunării de Jos, deodată cu alte daruri pascale. De asemenea, studenții teologi s-au implicat în acțiunea de pregătire a pliculețelor cu „pască“ - peste 30.000 - care s-au împărțit credincioșilor în Vinerea și Sâmbăta Mare, la Catedrala Arhiepiscopală din Galați. Cei mai mulți dintre studenții teologi gălățeni au împărțit credincioșilor, la parohiile lor, stâlpările - de Florii şi Sfânta Lumină - de Paști.

În etapa a III-a (10 aprilie-30 mai), marea majoritate a studenţilor și masteranzilor, grupați pe ani, au purces la identificarea unor cazuri sociale din proximitatea domiciliului lor. După vizitele preliminare, de cunoaștere reciprocă și de identificare a nevoilor specifice, atât cadrele didactice, dar și studenții au organizat colecte de bani, alimente, produse pentru igienă și curățenie; acestor colecte li s-au adăugat persoane cu putere economică, ce au înțeles gestul nobil al tinerilor și l-au susținut cu generozitate. Produsele respective au fost duse la domiciliul unor persoane cu reale nevoi, de către echipe de studenți, de multe ori însoțite de cadre didactice de la Departamentul Teologic sau de preoți din parohiile respective. În cele ce urmează, inserez câteva dintre impresiile voluntarilor, care descriu trăirile $\operatorname{lor}^{38}$ din această perioadă:

„Pe toată durata lunii aprilie am făcut cumpărături și am dus alimente acasă, bătrânilor și alor persoane vulnerabile din localitatea Răchitoasa, județul Bacău, acolo unde locuiesc eu. Când a fost nevoie, am ridicat rețetele lor de la medicul de familie și le-am dus medicamentele acasă“" (Liliana Diaconu, anul I TOAS).

„Am participat la mai multe acțiuni de voluntariat, organizate în beneficiul unor persoane cu mari probleme materiale, și desfășurate în satul Bogza și în orașul Râmnicu-Sărat, unde locuiesc eu. De Florii, în ziua de 11 aprilie am împărțit ramuri de salcie, binecuvântate de preot la biserică, în cartier" (Angelica Șerban, anul I TOAS).

„Am participat la acțiuni de voluntariat în localitățile Râmnicu-Sărat și Greabănu. Am luat aghiasmă de la Izvorul Tămăduirii și am împărțit

38. Sondajul la nivelul studenților și masteranzilor a fost făcut de către semnatarul studiului de față, la jumătatea lunii mai 2020. 
celor izolați. Am aprovizionat persoane vârstnice, de-a lungul perioadei de carantină, cu alimente, pentru dumnealor și animalele din gospodărie, cu rețete pe care le-am procurat în numele acestor persoane de la medicul de familie, iar pe cele cu probleme mai grave de sănătate le-am transportat la secția primiri urgențe, pentru evaluare" (Annemarie Dat$\mathrm{cu}$, anul I TOAS).

„De la începutul stării de urgență m-am ocupat săptămânal sau de câte ori a fost nevoie de achiziționarea celor necesare unor doamne în vârstă, care locuiesc pe aceeași scară cu tatăl meu. Am cumpărat săptămânal și am oferit alimente unei familii vecine, compusă din 6 persoane, care primește doar 280 lei, ca ajutor social. Împreună cu un coleg am cumpărat alimente pentru o familie care a solicitat ajutor în data de 3 aprilie. Familia nu mai avea mâncare de 2 zile și este compusă din 4 adulţi și 2 minori! Le-am oferit mâncare caldă, dar și alimente pentru o săptămână. Am participat la acțiunea amplă, organizată de Sfânta Arhiepiscopie și am luat legătura - telefonic, ritmic - cu 4 doamne în vârstă, oferindu-le posibilitatea de a apela ori de câte ori au nevoie de ceva în această perioadă“ (Laura Cristina Ciobotaru, anul I TOAS).

„Am adus credincioșilor din parohia Umbrărești, jud. Galați, Lumina Sfântă, anaforă și «paști», cât și cuvântul pastoral transmis de ÎPS Părinte Casian. Am distribuit, unde s-a solicitat, obiecte de cult, fiind voluntară la pangarul bisericii și am ajutat și la alte activități bisericești, precum: împărțirea de alimente și mâncare gătită persoanelor nevoiașe. M-am implicat în programul de ridicare a schelei pentru pictarea bisericii“ (Teodora Angheliu, anul II TOAS).

„Am participat, împreună cu preotul paroh și cu alți voluntari ai bisericii din Ianca, la distribuirea celor necesare (alimente), persoanelor aflate în neputințe. Am făcut cumpărături din proprie iniţiativă, de alimente și medicamente, pe care le-am dus tuturor celor care au cerut ajutorul. Am aprins lumânări la toate mormintele din cimitir de «Paștele Blajinilor»" (Cristi Ștefănuț Iancu, anul II, TOAS).

„Pe toată durata lunilor aprilie și mai 2020 am purtat nenumărate covorbiri telefonice cu persoane izolate și diagnosticate cu virusul Covid 19, pe care le-am încurajat și susținut din punct de vedere moral. În Parohia «Sfânta Ana» din Galați am ajutat la distribuirea alimentelor la domiciliul bătrânilor din evidența parohiei. Am făcut demersurile legale pentru obținerea unui număr de SMS, pentru donații către sistemul medical național" (Jeni Lipșa, anul II TOAS). 
„De mai bine de o lună viețile noastre s-au schimbat, fiind nevoiți să renunțăm la unele dintre activităţile noastre. Ni s-a transmis clar şi răspicat îndemnul: «Stați în casă!» și mulți dintre noi am înțeles aceasta ca pe o izolare completă și o înstrăinare de apropiații noștri, ceea ce este greșit. După cum bine am văzut, Biserica și-a întins brațele și s-a implicat activ în ajutorarea tuturor celor aflați în dificultatea provocată de această pandemie ce a cuprins lumea întreagă. În urma activităților social-filantropice realizate de Biserica noastră Ortodoxă, aceasta a devenit un exemplu demn de urmat pentru noi toți. Personal, am urmat exemplul Bisericii şi am încercat să fiu de ajutor comunității din care fac parte. Astfel, am ajutat o proaspătă mămică, dăruindu-i cele necesare pentru îngrijirea bebelușului abia adus pe lume, mi-am ajutat bunicii la pregătirea pentru Sărbătoare Învierii și, nu în cele din urmă, am ținut legătura cu persoanele vulnerabile din apropierea mea, ajutându-le cu o vorbă caldă sau cu diverse lucruri sau alimente" (Ana Valentina Tomeci, anul III TOAS).

"De mai multe luni fac voluntariat la doi bătrâni de 90 de ani: le fac cumpărături, le rezolv diverse treburi gospodărești, îi ajut cu tot ce au trebuință. Am fost alături de ei în toată această perioadă“ (Giovana Maria Lelcu, anul II master SOAS).

„Sunt voluntar la Parohia «Sfinții Martiri Brâncoveni» din Galați și coordonator al grupului de studenți și masteranzi teologi voluntari de la Centrul Eparhial al Arhiepiscopiei Dunării de Jos. Am pregătit Pască - la parohie și la Centrul Eparhial, am împărțit daruri pascale - salcie, pască, Lumina Sfântă - credincioșilor din cartier. Bătrânilor din blocurile vecine le-am dus anaforă și aghiasmă, duminica și în zilele de sărbători. Pe toată perioada lunilor martie-mai am dus hrană caldă unei persoane aflate în izolare" (Mariana Şerban, anul II master SOAS)

"Ca preot în parohia Surdila Greci, jud. Brăila, am coordonat, la nivelul parohiei, mai multe proiecte social- filantropice, în beneficiul persoanelor aflate în situații limită din zona noastră, pregătind și desfășurând programele după modelul oferit de Arhiepiscopia Dunării de Jos. Am împlinit tot programul liturgic al Postului Mare și al perioadei pascale, acest lucru având un impact deosebit de puternic și de benefic asupra comunităţii în care slujesc" (pr. Valentin Zota, anul II master SOAS).

„Am stat câteva săptămâni în carantină, împreună cu bătrânii de la Centrul de îngrijire a persoanelor vârstnice «Sfântul Ștefan cel Mare» din Galați, unde lucrez. Am participat la întregul program zilnic, sanitar, social și de rugăciune, cu bătrânii“ (Atena Enică, anul II master SOAS). 
Prin aceste acțiuni filantropice au fost ajutate și susținute peste 1000 de persoane din localități aparținând județelor Galați, Brăila, Tulcea, Buzău, Vrancea, Vaslui, Bacău, acolo unde locuiesc cei 110 studenţi și masteranzi voluntari de la Departamentul Teologic gălățean ${ }^{39}$.

\section{Pași duhovnicești spre Paști.}

Stâlpări pentru popor, semne de speranță și viață

La Paștile anului 2020 creștinii au arătat întregii lumi că pot prăznui cuviincios, după rânduiala lor, și în condiții speciale, de restricții maxime. Din vreme, Arhiepiscopia Dunării de Jos a purces la o pregătire specială, în baza "Îndrumărilor"40 echilibrate pe care Sfânta Patriarhie le-a oferit clerului și credincioșilor. Aceste „Îndrumări“ au ajutat la o organizare perfectă și la o derulare fără niciun incident a sărbătorilor pascale.

Primii „pași“ duhovnicești spre sărbătoarea pascală l-au constituit pregătirea și însăși prăznuirea Floriilor. Deși pelerinajul tradițional de Florii nu s-a putut organiza, mare mângâiere sufletească a generat credincioșilor programul misionar de aducere a ramurilor de salcie, de către voluntari, de la biserici la casele creștinilor. În fiecare parohie, de Florii, după Sfânta Liturghie echipe de tineri au dus creștinilor din case ramuri de salcie, sfințite, simbolurile credinței mereu vii și luminoase. Impactul a fost major, în toată eparhia: creștinii ortodocși au primit astfel semn binecuvântat la încheierea Păresimilor și imbold duhovnicesc pentru a începe cu speranță și a săvârși cu împliniri lăuntrice calea Săptămânii Mari.

Multe parohii au urmat sugestia arhipăstorului nostru și au pregătit din vreme „pachete de suflet ${ }^{\text {“41 }}$, conținând o carte de zidire su-

39. Un material complet despre aceste aspecte, la pr. Lucian PETROAIA, „Ajutorul studenților teologi gălățeni în timpul pandemiei“, în: Ziarul Lumina, nr. 106 (4579), 9 iunie 2020, p. 9, col. 1-4.

40. Cancelaria Sfântului Sinod, „Îndrumări ale Cancelariei Sfântului Sinod, aprobate de Patriarhul României, privind slujbele de Florii, din Săptămâna Mare (a Sfintelor Pătimiri) și de Sfintele Paști, în condițiile stării de urgență“, în: Ziarul Lumina, nr. 70 (4543), 10 aprilie 2020, p. 7, col. 1-3; publicate și în: Călăuză ortodoxă, XXX (2020), nr. 377, pp. 8-10.

41. îPS Arhiepiscop dr. CASIAN AL DUNĂRII DE Jos, „Rugăciune, comuniune, filantropie“, în: Călăuză ortodoxă, XXX (2020), nr. 377, p. 18. 
fletească, tămâie, cărbuni, candela pascală, lumânări. S-au adăugat, uneori, un pachețel cu anaforă, o sticluță cu agheasmă, o iconiță, revista eparhială „Călăuză ortodoxă“. Daruri pline de semnificații duhovnicești! Ele au pregătit terenul spiritual pentru sărbătoarea pascală, cu salba ei de bucurii tainice și cu neputință de confiscat, nici măcar de adumbrit!

Așa s-a organizat, prin parohii, primul „val de voluntariat", care a animat tineri și maturi dispuși să facă bucurie semenilor lor. Acțiunea de Florii s-a constituit, de fapt, într-un exerciţiu „pe viu“ sau într-o simulare anticipând realizarea programelor pascale propriu-zise, care se apropiau și care necesitau derulare fără greș, având în vedere restricțiile perioadei.

\section{Darul Joii Mari:}

\section{„Pâinea care se cheamă în popor «Paști»"}

Întrucât credincioșii fuseseră anunțați de autorități că nu aveau să poată participa, în noaptea pascală, la Slujba Învierii, Patriarhia Română a găsit o a doua formă de mângâiere sufletească: distribuirea în popor, din timp, prin voluntari, a pâinii ce se cheamă „paști“. „Pasca" fost sfințită, în toate mănăstirile și bisericile, în Sfânta și Marea Zi Joi din Săptămâna Sfintelor Pătimiri. Gândirea teologică a susținut perfect intuiția pastorală a Preafericitului Părinte Patriarh Daniel, de a lega momentul sfințirii pâinii - „paști“42 de Sfânta și Marea Zi Joi, când Mântuitorul Hristos a întemeiat Taina Sfintei Euharistii. Această legătură a generat efectul unui proiect pastoral-misionar de proporții naţionale: în toate eparhiile, credincioșii au putut primi „pasca“, și-au putut mângâia sufletele și și-au putut alina dorul de sfintele slujbe.

În Arhiepiscopia Dunării de Jos, prin coordonarea ÎPS Arhiepiscop Casian, „pasca“ a fost adusă în casele creștinilor de voluntarii din parohii. A fost al doilea exercițiu, impecabil realizat, care a pregătit proiectul misionar din noaptea pascală. „Pâinea - paști“ a dus în inimile și în familiile creștinilor, pe puntea duhovnicească dintre credincioși și

42. Conform rânduielii liturgice, în condiții obișnuite, pâinea numită în popor „paști“ se sfințește în cadrul Sfintei Liturghii din noaptea pascală, la momentul cântării „Axionului“ - Liturghier, ed. cit., pp. 416-417. 
bisericile lor parohiale, binecuvântarea Mântuitorului Iisus Hristos, numit de cântările bisericești „Paștile noastre“.

\section{Darul Sfintei Lumini, în vremuri înnegurate}

Și în anul 2020, în condiții cumplite, de pandemie, prin delegația condusă de PS dr. Timotei Prahoveanul, Episcop-Vicar al Arhiepiscopiei Bucureștilor, Patriarhia Română a adus românilor creștini ortodocși, de la Ierusalim, darul Sfintei Lumini ${ }^{43}$. Efortul Sfintei Patriarhii s-a făcut „pentru a nu fi întreruptă tradiția începută în anul 2009 (...) mai ales în această perioadă în care speranța și lumina trebuie aduse în sufletele oamenilor" ${ }^{\prime 44}$.

Cu multă scumpătate, cu mare evlavie și cu emoție de nedescris, semnul cel mai vădit al iubirii Mântuitorului Înviat, Sfânta Lumină, a fost preluat(ă) de la aeroport și de delegația Arhiepiscopiei Dunării de Jos. A urmat apoi neverosimil de rapida călătorie a Luminii spre Brăila și Galați, apoi miraculoasa împărțire a ei, fără ca ea să se împuțineze, ci dimpotrivă, amplificându-se în mâinile tremurătoare de emoție ale zecilor și sutelor de mii de persoane care au primit-o în nici două ceasuri! Aceeastă lucrare măreață s-a realizat prin jertfelnicia a aproape 2500 de voluntari, câte cinci din fiecare parohie din eparhie, care au dus Lumina, în dar, tuturor.

Primirea Sfintei Lumini și împrăștierea ei fulgerătoare, în doar câteva ceasuri, până la cea mai retrasă casă de creștini, din cel mai îndepărtat cătun, confirmă iarăși iubirea infinită pe care Dumnezeu o are pentru neamul românesc ${ }^{45}$. Dar confirmă și forța unității credinței și

43. Arhid. Ştefan SFARGHIE, „Sfânta Lumină de la Ierusalim a fost adusă şi anul acesta în țară", în: Ziarul Lumina, nr. 75 (4548), 22 aprilie 2020, p. 7, col. 1-4; A. BUTU, „Sărbătoarea Învierii Domnului la Catedrala Patriarhală“, în: Ziarul Lumina, nr. 75 (4548), 22 aprilie 2020, pp. 8-9, col. 1-6; Alte relatări despre Slujba Învierii, săvârșită la catedralele din Galați, Huși, Baia Mare, Oradea, Slobozia, Tulcea în Ziarul Lumina, nr. 76 (4549), 23 aprilie 2020, pp. 3-5, 7, col. 1-4.

44. Cancelaria Sfântului Sinod, „Îndrumări..., în: Ziarul Lumina, nr. 70 (4543), 10 aprilie 2020, p. 7, col. 1.

45. Mărturii emoționante de la creștini ortodocși din București, Ilfov, Iași, Cluj, Târgoviște, Argeș, Bacău, Vrancea, Galați și chiar din străinătate (Statele Unite, An- 
iubirii de semeni de care au dat dovadă voluntarii. Preoții au organizat perfect această acțiune, la nivelul parohiilor. Au selectat tineri inimoși și curați la suflet, i-au instruit conform cerințelor Patriarhiei și Arhiepiscopiei, i-au dotat cu făclii, felinare sau candele anti-vânt, aprinse cu Sfânta Lumină preluată direct de la ÎPS Arhiepiscop, la Catedrală (preoții din orașul Galați) sau de la părinții protopopi, în bisericile prestabilite ca puncte de întâlnire (preoții din celelalte zone ale eparhiei). Pe acești tineri voluntari, preoții i-au trimis, ca pe niște „apostoli ai luminii“, spre casele și sufletele creștinilor. Nu s-au semnalat nemulțumiri. Nu s-a înregistrat nicio situație nedorită. $\mathrm{Nu}$ s-a contaminat nimeni! Toate chipurile și toate sufletele au strălucit de „Lumina lui Hristos, care luminează tuturor".

A fost unul dintre cele mai bine puse la punct și mai reușite dintre programele pastoral-misionare derulate de Eparhia noastră din ultimele trei decenii. În condiții grele și într-o stare de spirit apăsătoare, pe care doar Sfânta Lumina le-a risipit puțin. Despre această prăznuire, unică în felul ei, scrie și ÎPS Părinte Casian, în „Pastorala la praznicul Învierii Domnului“" din anul acesta:

„(...) ne mulțumim de primirea luminii Sale (a Domnului Hristos înviat, s.n.) și de prezența Sa duhovnicească în inimile noastre! Este o mutaţie de la apropierea fizică la cea duhovnicească! (...) în locul bisericilor pline de credincioși și al mulțimilor primitoare de lumină pascală, contemplăm duhovnicește lumina din sufletele devenite «candele» luminoase, iar casele dumneavoastră le vedem luminate ca pe niște biserici!"46

Astfel, cea mai mare sărbătoare creștină, văduvită anul acesta de prezența credincioșilor, a putut fi simțită în toate casele de creștini, așa cum odinioară se întâmpla, discret dar luminos, în vremuri tulburi, în bisericile-catacombă din perioada de început a creștinismului sau în bisericuțele-bordei ale românilor din secolele XVII-XVIII.

glia), la Tudor Cătălin ZARojANU, „Am biruit lumea!“, Ziarul Lumina, nr. 75 (4548), 22 aprilie 2020, pp. 12-13, col. 1-6.

46. ÎPS Arhiepiscop dr. CASIAN AL DUNĂRII DE Jos, „Învierea Domnului - izvorul sănătății noastre. Pastorală la Învierea Domnului“, în: Călăuză ortodoxă, XXX (2020), nr. 377, p. 6. 


\section{Pelerinajul tinerilor \\ la Mănăstirea Buciumeni}

În condiții speciale, pelerinajul tinerilor la hramul de la Buciumeni (ediţia a XXV-a) a fost realizat de o manieră specială, și anume printr-o amplă întrunire on-line pe care a provocat-o și prezidat-o ÎPS Arhiepiscop Casian. 0 întâlnire „pe Net", cu tineri din toate liceele de pe teritoriul eparhiei, în duh de rugăciune și în bucuria „pelerinajului dorinței" este, într-adevăr, o idee insolită, care arată capacitatea Bisericii de a converti mijloacele moderne de comunicare în instrumente pentru pastoraţia tineretului, în condiții speciale ${ }^{47}$. Ideea, realizată în condiții tehnice excelente, arată preoților că, pentru situații excepționale trebuie inovate și utilizate metode pastorale speciale. În fond, această formă de pelerinaj a chemat, încă o dată și de această manieră, sufletele tinerilor la rugăciune, la redescoperirea programelor culturale și la implicarea dinamică în voluntariate, spre folosul semenilor. În concret, tinerii au înaintat pomelnice cu numele celor din familiile lor și au fost pomeniţi la „altarul din catedrala cu vitralii foșnitoare" de chiriarhul nostru, dar și-au exprimat și gândurile lor curate, prin cuvinte memorabile. Citez câteva fragmente, dintr-o carte a ÎPS Casian, recent apărută:

„Nu am mai fost la biserică în ultima vreme, dar Dumnezeu a venit în biserica din sufletul nostru, la noi acasă" (Mirela Postolache, clasa a IX-a, Liceul „Paul Dimo“, Galați).

„La urma urmei, iubirea nu te ține legat de un stâlp, te eliberează și îți dă aripi pentru a zbura cu ele, te împinge de la spate și te susține în tot ce faci (...) Iubirea e înțelegere reciprocă, fidelitate și încredere" (Cristina Matei, clasa a IX-a, Colegiul Naţional "Spiru Haret", Tecuci).

„Timpul petrecut în casă în toată această perioadă mi-a deschis în suflet imaginea unei corăbii, în care noi toți, deși suntem la distanță, călătorim împreună, ajutându-ne, iubindu-ne și descoperindu-ne pe marea vieții, cu toții având aceeași țintă, spre Dumnezeu. Când marea vieții este învolburată, când suntem vulnerabili și expuși, Dumnezeu nu ne

47. V. R. NECHIFOR, „Întâlnirea tinerilor în Eparhia Dunării de Jos, organizată în condiții speciale“, în: Ziarul Lumina, nr. 104 (4577), 4 iunie 2020, p. 3, col. 1-2; V. R. NECHIFOR, „Pelerinaj de tradiție la sărbătoarea hramului Mănăstirii gălățene Buciumeni“, în: Ziarul Lumina, nr. 107 (4579), 10 iunie 2020, p. 6, col. 1-2. 
lasă niciodată. Dumnezeu este întotdeauna ancora orizontului nostru și mereu ne aduce spre El, în siguranță, pe malul dumnezeirii“ (Ana-Maria Crintea, clasa a XI-a, Liceul Tehnologic „Paul Dimo“, Galați).

„Din nefericire s-a încetățenit în rândul oamenilor ideea că un tânăr credincios este rupt total de viața socială. (...) Un tânăr care vrea să fie bineplăcut lui Dumnezeu se deosebește prin selecția alegerilor pe care este chemat să le facă. El le va trece pe toate prin prisma relației lui cu Hristos: «Oare, Îi place lui Dumnezeu ce fac sau ce urmează să fac eu acum?»" (Bianca Jușcu, Colegiul Național "Costache Negri“, Galați).

„Am învățat că rugăciunea este cheia Raiului și că deschide porțile harului divin. Rugăciunea este necesară pentru a ne întări în suferințe și slăbiciuni, pentru a ne scăpa de frică și de gânduri rele. Este un leac care vindecă orice rană, oprește orice lacrimă și orice durere, care dă liniște“ (Denisa Ion, clasa a XI-a, Liceul Tehnologic Însurăței, Brăila).

„Am văzut persoane în suferință. Tristețea li se citește pe frunte, în privire, în mâna șovăielnică și tremurândă...M-am întrebat: când mai pot zâmbi aceste persoane? Cum pot eu, cu un simplu gest, să le șterg cuta amărăciunii din inimă? Cum pot aduce bucurie în ochii celui care lăcrimează a deznădejde? M-am rugat să devin mai bun și să știu cum să simt dragostea în privirea celui din fața mea, cum să ajut și cum să fiu de folos" (Marian Brătuleanu, clasa a XII-a, Liceul Tehnologic „Paul Dimo“, Galați).

„Departe de colegi și de prieteni, sufletul meu a înțeles nevoia distanțării sociale și fizice, dar și a unei altfel de apropieri. Am ales să construiesc pe interior un zid al prieteniei, cărămidă cu cărămidă, și am învățat că prietenia se clădește astfel, cu rădbare, ca să ne umplem toate golurile din inimă cu iubire, ca să nu mai simțim niciodată însingurarea“ (Elena Crintea, clasa a XI-a, Liceul Tehnologic „Paul Dimo“, Galaţi) ${ }^{48}$.

Despre aceste înalte trăiri ale tinerilor pelerini a publicat, spaţii largi, și cotidianul Patriarhiei Române ${ }^{49}$. Mai cu seamă ele au fost cuprinse, integral, într-un volum al ÎPS Arhiepiscop Casian, publicat de curând în Editura Arhepiscopiei Dunării de Jos ${ }^{50}$.

48. Texte preluate, fragmentar, de la ÎPS Arhiepiscop dr. CASIAN AL DUNĂRII DE Jos, Tinerii pelerini în Catedrala cu vitralii foșnitoare, Editura Arhiepiscopiei Dunării de Jos, Galați, 2020, pp. 63-134.

49. Tudor Cătălin ZAROJANU, „Minunatele gânduri ale tinerilor de la Buciumeni, în: Ziarul Lumina, nr. 108 (4581), 11 iunie 2020, pp. 8-9, col. 1-6.

50 . A se vedea nota 43 , de mai sus. 
Cel mai important lucru este că „Proiectul Buciumeni“ a mers mai departe! În 2021, când cele legate de pandemia cu COVID-19 sperăm să devină o amintire neplăcută, liceenii vor reveni acasă, în „catedrala“ lor din frunze și cer, vor cânta Domnului și își vor spune păsurile, iar sfințiţii slujitori îi vor binecuvânta și se vor bucura de ei, ca de fiii lor duhovnicești.

\section{Inițiative preoțesti remarcabile}

Ce minunat este când îi spui omului ceva și face ce spui, pentru că este spre binele lui și al altora! Cu atât mai frumos este atunci când, pentru a face bine, nu trebuie așteptat un ordin de la superiori, nu trebuie să existe vreo presiune sau vreun alt fel de obligație. Binele trebuie să vină de la sine! La acest nivel de conștiință poate ajunge omul atunci când se află în încercări mari. În condiții speciale, omul se înțelepțește și percepe altfel și viața lui, și viața semenilor. La această măsură a înțelegerii au ajuns, în pandemie, mulți dintre preoții de la Dunărea de Jos. Unii însă, deschizându-se sufletește lucrării lui Dumnezeu, au primit harisma ajutorării unor creștini aflați în situații extrem de grele. Evoc aici câteva dintre aceste fapte, remarcabile.

Cazul familiei Adam din localitatea Țibănești - Brăila a impresionat întreaga suflare a comunei. Costică Adam, văduv (tată a opt copii, dintre care unul a fost căsătorit și cu un copil) primește o altă grea încercare: îi arde casa, cu toate dependințele ei și chiar și livada. Părintele Vlad Dumitrache a preluat imediat cazul și, cu ajutorul unor binevoitori a condus proiectul de zidire a unei case noi pentru această familie. Din încredințarea ÎPS Arhiepiscop Casian, familia dlui prof. univ. dr. Alexandru Chiriac a susţinut dotarea casei cu toate cele necesare. Slujba de sfințire a noii case a fost săvârşită de chiriarhul Dunării de Jos, în data de 1 iulie $2020^{51}$, reprezentând momentul unei noi vieți la care a fost chemată familia Adam, de către Domnul, prin slujitorii Lui.

51. Detalii în articolul ÎPS Arhiepiscop dr. CASIAN AL DuNĂRII DE Jos, „Din casa omului încercat, dar binecuvântat", în: Ziarul Lumina, nr. 124 (4597), 3 iulie 2020, p. 1 și p. 9, col. 1-3. 


\section{Receptarea în mass-media a eforturilor \\ Arhiepiscopiei Dunării de Jos, de combatere \\ și reducere a efectelor negative ale pandemiei}

Efortul uriaș al Bisericii noastre nu a fost uneori remarcat sau evidenţiat, atât cât ar fi trebuit, de către mass-media laică. Uneori soluțiile misionar-pastorale și cele de factură sanitară, aplicate de Biserică pentru protejarea credincioșilor și adoptate contextual și pe termen scurt, referitoare la sărutarea icoanelor sau la primirea Sfintei Împărtășanii au fost colportate atât de virulent și de așa natură, încât ele să pară o definitivă victorie a laicatului modernist asupra „gândirii și practicii retrograde ale Bisericii“ ${ }^{\prime 52}$. Nu are sens să ne amintim aici de nenumăratele știri tendențioase $\mathrm{S}^{53}$ ori de avalanșa de fake-uri, care au creat dezorientare și panică ${ }^{54}$. În contrabalans, aşa cum și era firesc,

52. De exemplu, a se vedea https://www.digi24.ro/stiri/actualitate/social/ coronavirus-romania-patriarhia-romana-recomanda-evitarea-sarutarii-icoanelor-din-biserica-1267282 sauhttps://www.digi24.ro/stiri/actualitate/cum-vor-putea-merge-la-biserica-romanii-dupa-15-mai-triaj-observational-la-intrare-si-impartasanie-cu-ustensile-de-unica-folosinta-1304380.

53. De exemplu, https://www.zf.ro/eveniment/guvernul-orban-a-batut-palma-cu-biserica-ortodoxa-si-a-decis-sa-ii-19072761.

54. Cu toate acestea există, din partea unor personalități, recunoașteri și evidențieri ale implicării Bisericii noastre în susținerea populației, în vremuri de pandemie. Menționez pe domnul Klaus Iohannis, Președintele României, care, mulțumind Preafericitului Părinte Daniel, Patriarhul României, își arată recunoştința faţă de uriașa implicare a Bisericii Ortodoxe Române în strategia naţională de combatere a virusului ucigaș: „(...) Doresc să remarc faptul că, prin rugă și sprijin pentru cei aflaţi în dificultate, prin ajutor pentru cei din prima linie, Biserica Ortodoxă Română a participat consistent la efortul național de combatere a pandemiei. Sunt încredinţat că, în perioada care urmează, sub înțeleapta arhipăstorire a Preafericirii Voastre, Biserica Ortodoxă Română va fi sprijin pentru societatea noastră, îmbinând misiunea pastorală cu preocuparea pentru protejarea credincioșilor și ierarhilor săi, pentru o cât mai grabnică revenire la normalitate a României": Klaus Werner Iohannis, Președintele României, Mesaj citit la slujba de înmormântare a ÎPS Pimen. A se vedea http:// doxologia.ro/jertfa-pentru-ierarhul-lor-cine-sunt-bărbaţii-îmbrăcați-în-combinezoane-care-l-au-purtat-pe-ips-parinte (accesat la data de 23 mai 2020, ora 21.12). 0 altă voce, cu autoritate la nivel naţional și european, este cea a Președintelui Academiei Române, care arată că, deși „nu a existat niciodată, în istoria noastră, o închidere generală a bisericilor!" în situația de față Biserica Ortodoxă Română a putut identifica soluţii pastorale inteligente pentru a nu întrerupe legătura cu fiii ei şi pentru a-i 
presa bisericească centrală și locală și-a făcut însă, din plin, datoria, prezentând programele și proiectele bisericești ale perioadei ${ }^{55}$. Voi cita totuși câteva titluri ale presei laice care a văzut și a apreciat coerența programului pastoral-misionar și filantropic derulat de Arhiepiscopia Dunării de Jos, în perioada martie - august 2020, grație bunei-credințe și onestității deontologice ale jurnalistului bun creștin Costel Crângan, care a emis în spațiul virtual generice precum:

- Peste 2200 de oameni primesc de la Arhiepiscopia Dunării de Jos hrană și produse de igienă ${ }^{56}$;

- Sute de pachete cu materiale igienico-sanitare și cu hrană, distribuite de Arhiepiscopia Dunării de Jos ${ }^{57}$;

- Arhiepiscopia Dunării de Jos a donat 10.000 de măști de protecție pentru spitalele din Galați și Brăila ${ }^{58}$;

- Preoții de la Dunărea de Jos donează din salariile lor pentru dotarea spitalelor din Galați, Tecuci și Brăila ${ }^{59}$;

susţine. Exprimarea reflectă și dorul mistuitor pe care românii l-au avut în suflete, pentru sfintele slujbe din bisericile și mănăstirile lor iubite și pentru duhovnicii lor, în toată perioada acestei recluziuni - acad. Ioan Aurel PoP, Președintele Academiei Române, „Biserica în vremuri de restricții“, în: Lumina de Duminică, nr. 19 (747), 10 mai 2020, pp. 2-3, col. 2-8.

55. Subliniez faptul că am utilizat, ca fond bibliografic al studiului de față, mai ales articolele din „Ziarul Lumina“, cât și unele din revista eparhială „Călăuză ortodoxă", care prezintă obiectiv lucrarea atât de dinamică a Arhiepiscopiei Dunării de Jos, în perioada pandemiei. Pentru aceasta îmi exprim toată admirația față de preoții -„eroi“, ajutaţi de voluntarii jertfelnici și de mulți filantropi darnici și discreți, cu care eparhia noastră, sub păstorirea Înaltpreasfințitului Părinte Casian a reușit să găsească soluții într-o luptă cu implicaţii atât de subtile și imprevizibile pentru sufletele și viața păstoriților, pe termen mediu și lung.

56. Vezi https://adevarul.ro/locale/galati/foto-2200-oameni-primesc-arhiepiscopia-dunarii-jos-hrana-produse-igiena-1_5e70d97a5163ec4271fee686/index. html (accesat la data de 17 octombrie 2020, ora 20.22).

57. Vezi https://adevarul.ro/locale/galati/sute-pachete-materiale-igienico-sa nitare-hrana-distribuite-arhiepiscopia-dunarii-jos-1_5e79ceab5163ec427125-608 d/index.html (accesat la data de 17 octombrie 2020, ora 20.30).

58. Vezi https://adevarul.ro/locale/galati/arhiepiscopia-dunarii-jos-donat10000-masti-protectie-spitalele-galati-braila-1_5e81b3925163ec42714e48c5/index.html (accesat la data de 17 octombrie 2020, ora 20.33).

59. Vezi https://adevarul.ro/locale/galati/toti-preotii-dunarea-jos-si-au-donat-salariile-dotarea--spitalelor-galati-tecuci-braila-1_5e8453525163ec42715b5dba/index.html (accesat la data de 17 octombrie 2020, ora 20.35). 
Bucătăriile bisericilor, ultima speranță a bătrânilor singuri și a sărmanilor din Galați. Peste 2.000 de porţii de mâncare pleacă zilnic către ei $^{60}$;

- 3.000 de coșuri cu produse tradiționale de Paști oferite cadrelor medicale, carantinaților și celor aflați la datorie ${ }^{61}$;

- Mii de copii din județele Galați și Brăila au primit daruri de 1 iunie de la preoții Arhiepiscopiei Dunării de Jos ${ }^{62}$.

Alături de ziarul „Adevărul“, în care au apărut articolele citate mai sus, mai multe cotidiene locale s-au onorat a prezenta, ritmic și corect, lucrarea pastoral-misionară și filantropică a Arhiepiscopiei. Amintesc aici de „Viața liberă“, „Obiectiv Vocea Brăilei“, „Cetățeanul“, „Monitorul de Galați", "Realitatea de Brăila" și de jurnaliști precum Teodora Miron, Marian Gheorghe, Monica Paraschiv, Cornelia Petrescu, Ioana Tănase ${ }^{63}$. Ei au fost niște „binevestitori“ și „apostoli“ ai unei atât de importante lucrări de împărtășire a credinței în Hristos și a omeniei, în Eparhia Dunării de Jos, în vreme de pandemie.

\section{Câteva concluzii}

Deși uneori neînțeleasă și chiar criticată, Biserica a câștigat, duhovnicește, extrem de mult din acest clocot. Până la momentul de față a ieșit chiar întărită din marasmul generat de virus, așa cum - biruitoare - a depășit perioade mult mai grele, cu persecuții, tiranii, ideologii. Înțelepciunii sale istorice, generația noastră de slujitori îi aduce acum experiența unei conlucrări exemplare între ierarhie, preoțime și popor, spre binele tuturor românilor: din țară și din diaspora, din orașe și sate, bogați și săraci, intelectuali și necărturari, creștini și

60. Vezi https://adevarul.ro/locale/galati/foto-bucatariile-bisericilor-ultimasperanta-batranilor-singuri-sarmanilor-galati-2000-portii-mancare-pleaca-zilnic-ei-1_5e8dc47b5163ec427187739e/index.html (accesat la data de 17 octombrie 2020, ora 20.45).

61. Vezi https://adevarul.ro/locale/galati/3000-cosuri-produse-traditionale -pasti-oferite-cadrelor-medicale-carantinatilor-celor-aflati-datorie-1_5e9c2d445163ec4271e3e875/index.html (accesat la data de 17 octombrie 2020, ora 20.50).

62. Vezi https://adevarul.ro/locale/galati/mii-copii-judetele-galati-braila-primit-daruri-1-iunie-preotii-arhiepiscopiei-dunarii-jos-1_5ed62d935163ec42716a -8564/index.html (accesat la data de 17 octombrie, ora 20.55).

63. Toate articolele lor sunt publicate în volumul ÎPS Arhiepiscop dr. CASIAN AL DUNĂRII DE Jos, Rugăciune. Comuniune. Filantropie..., pp. 537-688. 
aparținători ai altor religii, creștini ortodocși, catolici, protestanți și neoprotestanți, credincioși și necredincioși.

În particular, programul atât de complex, liturgic, duhovnicesc, misionar, pastoral, social-filantropic al Arhiepiscopiei Dunării de Jos, dezvoltat pentru susținerea credincioșilor ei și derulat în doar câteva luni (martie - august 2020, dar continuă și în prezent - noiembrie 2020 - pentru atenuarea efectelor „valului 2“ al pandemiei) este cu neputință de cuprins în cifre și cuvinte! Este o lucrare impresionantă, copleșitoare prin jertfelnicia lucrătorilor (ierarh, preoți, voluntari, donatori) și prin bucuria și recunoștința zecilor de mii de beneficiari. Modul în care s-a organizat Eparhia noastră, încadrându-și organic proiectele proprii în strategia mare a Bisericii Ortodoxe Române pentru această perioadă, denotă luciditatea, realismul și capacitatea de empatie ale arhiepiscopului nostru și disponibilitatea rarisimă și capacitatea de jertfelnicie ale preoțimii dunărene. Să nu uităm nici de „revelația“ pe care am avut-o cu toții, în luna aprilie: forța uriașă a "credinței lucrătoare prin iubire" (Galateni 5,6$)$ de care au dat dovadă miile de voluntari. Prin cele trei mari exerciții de voluntariat, Eparhia a pus de fapt bazele unei culturi locale a voluntariatului. Aceasta îi va asigura mare parte din dinamismul misionar din viitor și va fi „unitatea de măsură“ a bunei pastorații a preotului, în parohie.

Dacă lucrarea letală a virusului sugerează cât de fragili și vulnerabili suntem în fața lui, oricât de avansată este știința medicală astăzi, lucrarea pastoral-misionară și filantropică dintr-o Eparhie ca a noastră se constituie într-o lecție-model despre om și omenie. Prin programele sale din această perioadă, Arhiepiscopia Dunării de Jos a arătat că, în vremuri grele, orice creștin trebuie să arate „Omul din om" și că trebuie să demonstreze faptic omenia dinlăuntrul inimii. Aceste programe au relevat și că în creștinii buni este multă dragoste de Dumnezeu și de om!

Reușita programelor de până acum probează puterea de coeziune a credinței, care creează comuniune și solidaritate, în vremuri de dezbinare a lumii, de izolare a omului și de atomizare a conștiințelor. Dacă Providența ne-a îngăduit o astfel de certare, cu molimă, frică și singurătate, tot de Sus ne vin puterea de a răbda, a lupta, a birui și capacitatea de a ne reevalua viața. Doar împreună, doar în Hristos și doar în Biserică. 